Article

\title{
Hydrothermal Carbonate Mineralization, Calcretization, and Microbial Diagenesis Associated with Multiple Sedimentary Phases in the Upper Cretaceous Bekhme Formation, Kurdistan Region-Iraq
}

\author{
Namam Salih ${ }^{1,2, *}$, Howri Mansurbeg ${ }^{3}$, Kamal Kolo ${ }^{1,4}$ and Alain Préat ${ }^{4}$ \\ 1 Petroleum Geosciences Department, Faculty of Science, Soran University, Soran 44008, \\ Kurdistan Region-Iraq; kamal.kolo@soran.edu.iq \\ 2 Scientific Research Center (SRC), Soran University, Soran 44008, Kurdistan Region-Iraq \\ 3 Petroleum Engineering Department, Faculty of Engineering, Soran University, Soran 44008, \\ Kurdistan Region-Iraq; howri.mansurbeg@gmail.com \\ 4 Res. Grp.-Biogeochemistry \& Modeling of the Earth System, Université Libre de Bruxelles, 1050 Brussels, \\ Belgium; apreat@ulb.ac.be \\ * Correspondence: namam.salih@soran.edu.iq or namam.muhammed@gmail.com
}

Received: 15 August 2019; Accepted: 23 October 2019; Published: 26 October 2019

\begin{abstract}
Hydrothermal diagenesis during the Zagros Orogeny produced three phases of saddle dolomites (SD1, SD2, and SD3) and two phases of blocky calcites (CI and CII) in the studied sections of Bekhme Formation (Fm) (Campanian-Maastrichtian). Field observations, as well as petrographic, cathodoluminescence (CL), Scanning Elecron Microscope (SEM), and oxygen-carbon isotope analyses, indicated that the unit went through multiple submergence-emergence phases after or during hydrothermal diagenesis. These phases resulted in a characteristic calcretized 2-6-m-thick layer within the Bekhme Fm. Several pedogenic textures (e.g., alveolar, pisolite, and laminar fabric microfeatures) were observed. Strong evidence of microbial alteration and diagenesis in this formation brings new insights into its depositional history. The microbial activities developed on the original mineral surface were associated with a great variety of processes including dissolution, re-precipitation, replacement, open-space fillings, microporosity development, grain bridging, and micritization. Probable oxalate pseudomorphs embedded in these fabrics and regular filaments preserved along crystal boundaries suggest the activity of fungi, while frequent coccoidal, rod-like, and chain-like forms attached to the surfaces of dolomitic and calcitic crystals point to bacterial colonization. Extracellular polymeric substance (EPS) was often visible with fungal and bacterial forms. These features, together with stable isotope data, invoke that near-surface conditions occurred sporadically in the Bekhme Fm after the first generation of hydrothermal dolomitization. These new findings allow recognition of unreported sedimentological phases based on new evidence in the Spelek-Sulauk area during the Upper Cretaceous.
\end{abstract}

Keywords: Bekhme Fm; biomineralization; calcretization; hydrothermal-microbial diagenesis; paleo-channel; sea-level fluctuation

\section{Introduction}

Hydrothermal mineralization and calcretization diagenetic processes involve specific paleo-fluid conditions, e.g., chemical composition of solution temperature and salinity, leading to altered rocks with particular petrographic and fabric textures [1]. In the literature, hydrothermal dolomitization (saddle 
dolomites) and calcretization are reported as two separate processes. Hydrothermal minerals (saddle dolomite and/or calcite) were documented in many localities [1,2]. Hydrothermal dolomitization (HT) is widely considered as a fault-related process [2], and/or related to the fluid flows associated with the migration of hydrocarbons [3]. Interestingly, hydrothermal dolomitization has a positive effect on oil migration pathways [4], such as enhancing migration and increasing porosities in the host carbonate rocks. Reference [4] asserted that many reservoirs associated with hydrothermal dolomitization are related to fault systems and, therefore, to the tectonic evolution of the series concerned. However, in the field, HT fluids appear globally restricted to the HT dolomite distribution; thus, their origins need detailed geochemical analyses [5].

Calcretization processes, contrary to HT processes, were widely recognized in environments submitted to various diagenetic conditions, either in the vadose zone related to pedogenetic alteration, or in the vicinity of the water table in the phreatic zone [6] and under low-temperature conditions (less than $50^{\circ} \mathrm{C}$ [7]). Calcrete processes are also factors, which affect reservoir properties, mainly porosity [8].

Bekhme limestone is defined to include reef limestones, fore-reef shoal limestones, and associated facies of the Upper Campanian to Lower Maastrichtian interval $[9,10]$. The paleo-environment of this formation is reported as a shallow marine condition in the carbonate shelf system [9]. Later on, Reference [11] studied Bekhme Formation in the Bekhme Gorge along the High Zagros Fold-Thrust, reporting that the formation of the saddle dolomite is attributed to the flux of hot undersaturated basinal/hydrothermal fluids into Cretaceous limestones of the Bekhme Formation along deeply rooted faults. Furthermore, the fluid inclusion and microthermometry indicated that the precipitation appeared to originate from hot $\left(81-115^{\circ} \mathrm{C}\right)$ basinal $\mathrm{NaCl}-\mathrm{MgCl}_{2}$ brines with salinities ranging from 18 to $22 \mathrm{wt} \% \mathrm{NaCl}$ equivalent [11].

The studied outcrops in the Spelek-Sulauk areas (Bekhme Formation, Campanian-Maastrichtian) are located in northeast (NE) Kurdistan near Sulauk village and Spelek highway (Figures 1 and 2). Structurally the outcrops are within the southwestern limbs of the Safin and Harir anticlines in the High Folded Zone. This study, which involves field observations, petrography, and geochemistry, is the first report in Iraqi Kurdistan on calcrete formation processes that superimposed hydrothermally dolomitized fabrics of Bekhme Formation.

This study aims to (1) provide a better understanding of alteration mechanisms in Bekhme Formation (Fm) and fluid-related processes within a hydrothermal framework, with particular petrographic insight into saddle dolomites and blocky calcites, (2) describe and characterize the hydrothermal and calcrete minerals, and (3) discuss the paragenetic sequence and specify the origin and conditions of the HT fluid flows and the origin of calcretization products. 


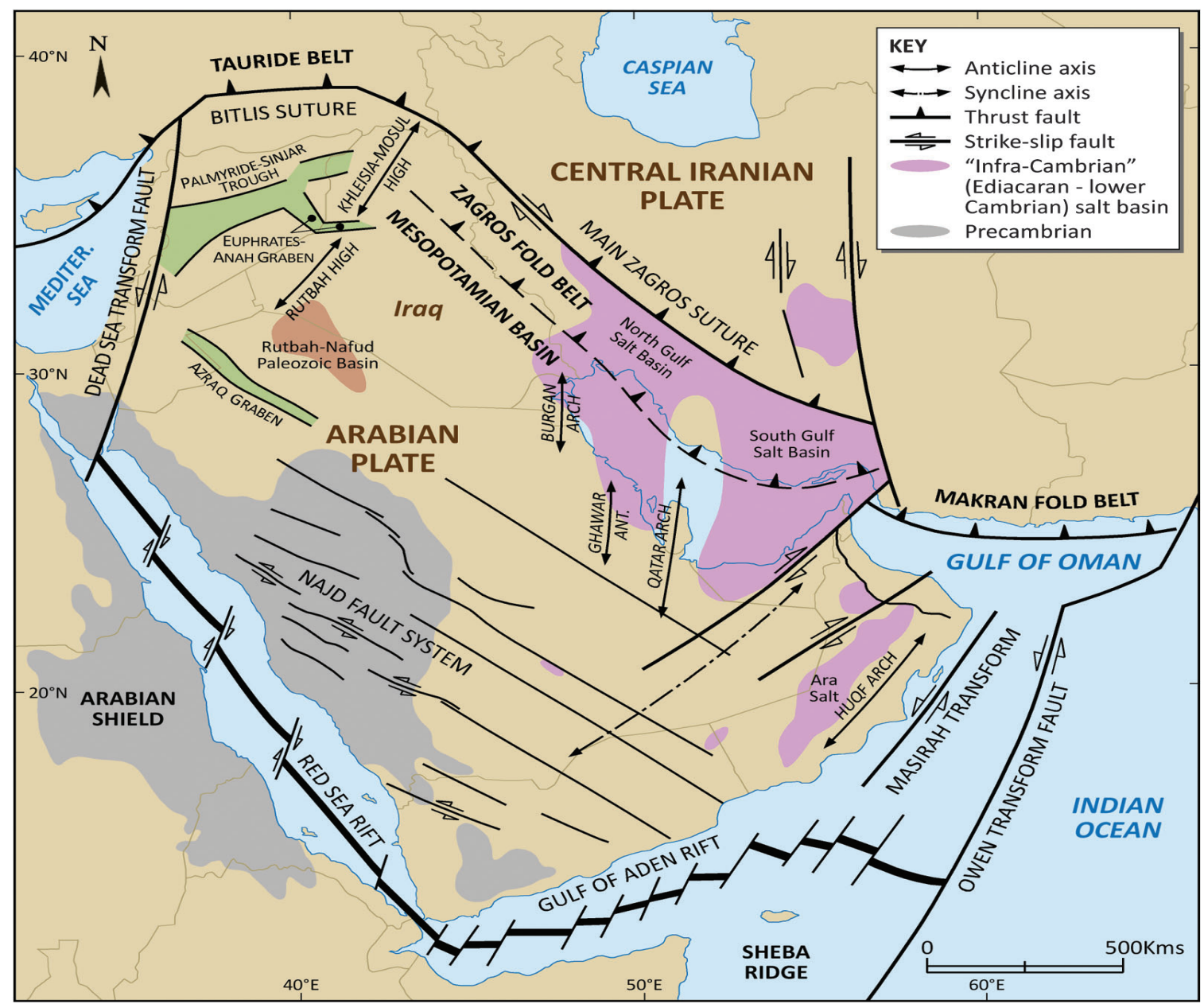

Figure 1. General map illustrating the Zagros fold-thrust belt (ZFTB) within the Kurdistan region of Iraq (after Reference [9]). 


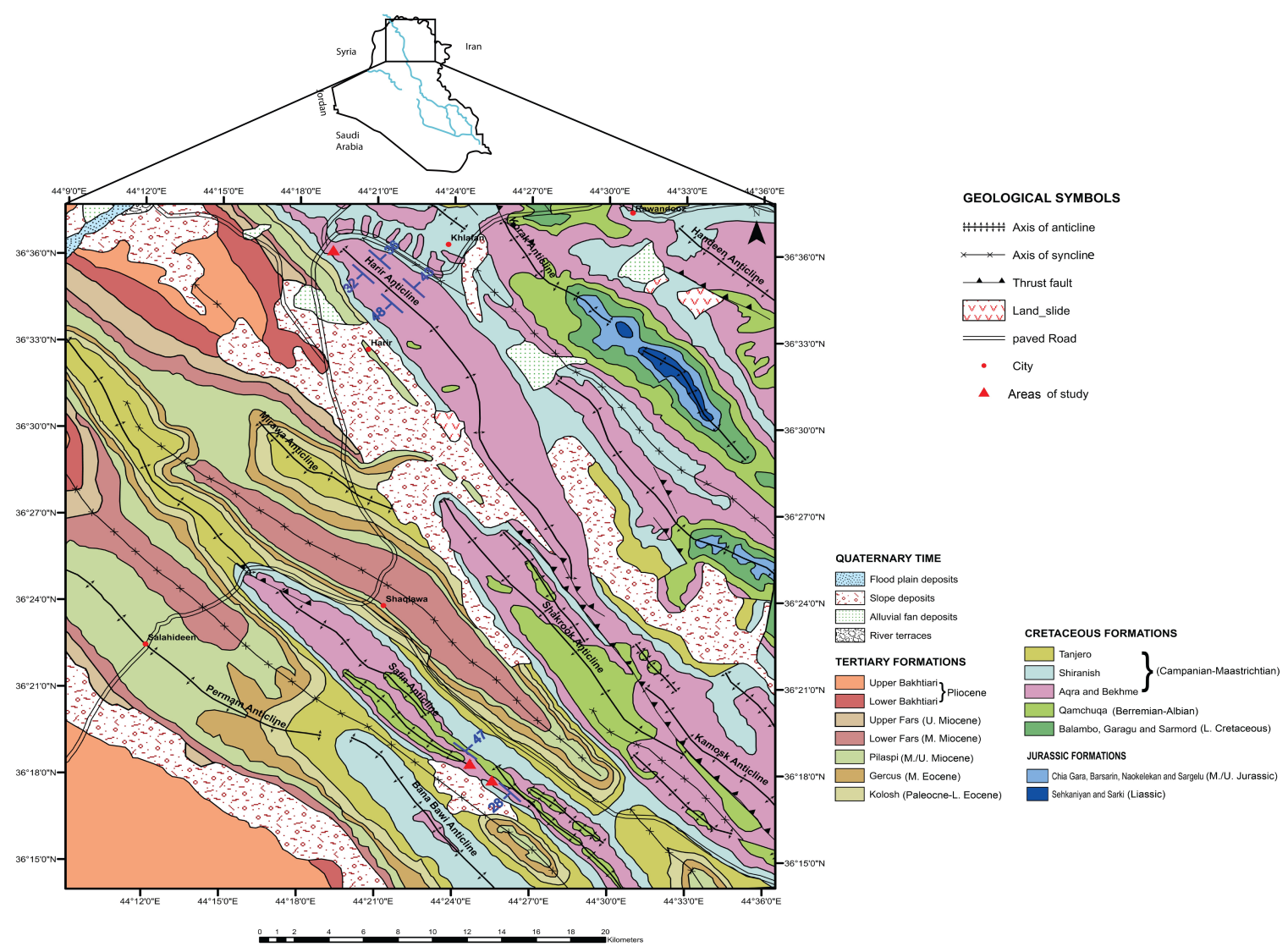

Figure 2. Geologic map of the Upper Cretaceous and Tertiary Basins showing related tectonic elements, geological units, facies distribution, and location of studied (Spelek-Sulauk areas) in the High Folded Zone.

\section{Geological Setting}

The Upper Cretaceous Bekhme Fm at the Spelek and Sulauk outcrops are situated within the Zagros fold-thrust belt (ZFTB), Kurdistan Region, northeast Iraq (Figure 1). The Formation outcrops are at the northwest (NW) limbs of the Harir and southeast (SE) of Safin anticlines, respectively (Figure 2). The development of the ZFTB was a response to the ongoing collision of the Arabian and Eurasian plates [12] and relatively comprised coherent blocks trending NW-SE [13].

The opening of the Neotethys oceans was initiated in the Permian and associated with rifting along the Zagros fold-thrust belt with extension along both passive margins in Late Triassic [13]. The Triassic passive margin was followed by Jurassic-Miocene arc-continent collision and ophiolite obduction along the Arabian plate (see Figure 3) [12]. After all, post-orogenic strike-slip faulting was developed, and the segmentation of Harir and Safin anticlines (NW-SE trend) was divided into four blocks in each anticline [14]. These blocks were bound by strike-slip/oblique faults controlled by basement movements along the detachment surface [15]. The strike-slip/oblique faults with an NE-SW trending direction which transversed the Harir and Safin anticline perhaps reflect the development of a post-orogenic faulting system after the collision between the Arabian and Eurasian plates. 


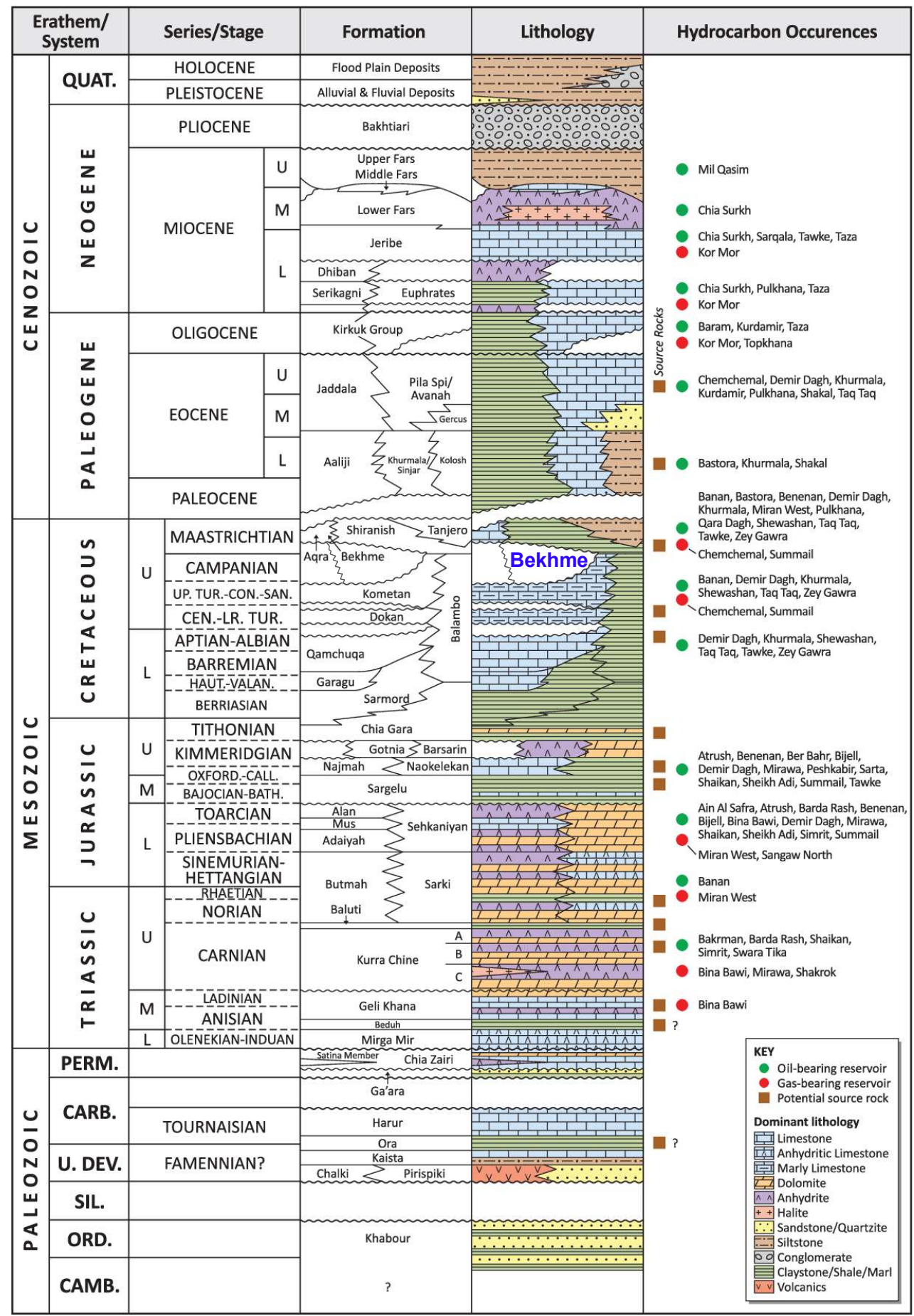

Figure 3. Phanerozoic stratigraphic column illustrating the age, lithology, and nomenclature for the principal stratigraphic units and tectonic events for the northwest (NW) Zagros foreland basin in the Kurdistan region of Iraq (after Reference [9]).

\section{Sampling and Methods}

Detailed fieldwork was carried out at the Spelek and Sulauk outcrops of Harir and Safin anticlines, respectively (Figure 2). Around 200 samples were collected from the limestones, dolomites, and calcites at different litho-stratigraphic levels, mostly following the NW-SE direction of HT bodies. Lateral and vertical samplings were carried out in order to follow the direction of fluids, and to 
outline any significant variations. Most sampled levels hosted saddle dolomite and blocky calcite HT minerals, different calcrete profiles, and different stratigraphic levels of host limestone facies of Bekhme Formation. Thin sections were prepared at the standard $30 \mu \mathrm{m}$ thickness and petrographically studied under standard polarizing and reflecting microscopes. Cold cathodoluminescence microscopy was performed on host limestone, dolomite, and calcite minerals. The approximate average measurements during cold cathodoluminescence microscopy were around $12 \mathrm{kV}$ accelerating voltage with $400 \mu \mathrm{A}$ beam current intensity, whereas a beam width of $0.5 \mathrm{~cm}$ inside a vacuum with a pressure below 0.05 Torr was given. Gold-coated thin sections and chips of limestones, dolomites, calcites from host limestones, and calcretes were studied with an FEI Quanta 450 Scanning Electron Microscope (SEM) to visualize the microbe-mineral interactions, micro-sized textures, porosities, and other dissolution-replacement processes. The oxygen and carbon stable isotopic compositions of samples were prepared, whereby carbonate powders were reacted with $100 \%$ phosphoric acid at $70{ }^{\circ} \mathrm{C}$ using a Gasbench II connected to a ThermoFisher Delta V Plus mass spectrometer. All values are reported in per mille (\%o) relative to Vienna Pee Dee Belemnite (V-PDB). Reproducibility and accuracy were monitored by replicate analysis of laboratory standards calibrated to international standards NBS19, NBS18, and LSVEC. Laboratory standards were calibrated by assigning $\delta^{13} \mathrm{C}_{\mathrm{VPDB}}$ values of $+1.95 \%$ o to NBS19 and $-46.6 \%$ o to LSVEC and by 23 assigning $\delta^{18} \mathrm{O}_{\mathrm{VPDB}}$ values of $-2.20 \%$ o to NBS19 and $-23.2 \%$ o to NBS18. The analyses $(\sim 154)$ were performed at the University of Erlangen (Germany, Prof. M. Joachimski).

\section{Results}

\subsection{Field Observations}

Bekhme Fm in the Spelek-Sulauk area was almost entirely altered in the lower part (Figure 4). Although the region underwent a complex diagenetic history, the original depositional facies of the Bekhme Fm were partly preserved, composed of massive rudist and coral boundstone (Figure 4A).

The Spelek and Sulauk outcrops were around $22 \mathrm{~m}$ and $15 \mathrm{~m}$ thick, respectively. The basal parts in both sections were extensively dolomitized, with dolomites filling the abundant geodes, and with fractures aligned parallel to the stratification in Spelek and parallel to sub-vertical in Sulauk section (Figure 4A).

The observed dolomite phases displayed mainly two types of dolomites: fracture-filled dolomite and brecciated dolomite crystals. The former postdated the latter. Fracture-filled dolomite was absent at the lower part of the flanks along Harir and Sulauk blocks. The no longer active HT fluids were close to the end of their flanks.

The sections showed two levels of 2-6-m-thick calcretes interbedded with well-bedded massive dolomitic limestones and dolostones, displaying gray, yellow, brown, and white colors (Figure 5). The basal part of these outcrops showed abundant linear, spherical, and ellipsoidal voids filled by dolomitic and calcitic cements (Figure 4A,B). These voids constituted interconnected elongated geodes of up to $25 \mathrm{~cm}$, allowing for good lateral continuity parallel to the bedding planes, and they were associated with 2-11-cm elongated chert nodules and lenses (Figure 4A). The oval-rounded geodes were filled with saddle dolomite and blocky calcite crystals and were often present together with fractures (Figure 5A) stacked in bands parallel or sub-vertical to the bedding in Sulauk section, a setting which occasionally displayed a zebra-like structure. Dolomite breccias and zebras were abundant in the Sulauk section, but were absent in Spelek section. These dolomites were reported as a late diagenetic originated from hot fluids in Bekhme Formation [11,16].

The hydrothermally altered basal part of Bekhme Formation in the Spelek outcrop ( $\sim \mathrm{m})$ was diagenetically influenced by another phase of calcrete (Figure 5A,B); the host limestone there was indistinctive because of complete exposure to calcrete alteration (Figure 5A). The basal part of Sulauk was diagenetically affected by these fluids and fully brecciated ( $2 \mathrm{~m}$ thick), and there was no sign of calcrete alteration; however, it was overlain by a calcrete profile from upper part, in places where a 20-40-cm-thick discontinuous bed of Ostracodean dolomitic limestone microfacies (Figure 5A) occurred. 
The most significant features in this particular level were the vertical and lateral variability of the fabrics (Figure 4, Figure 5, Figure 6A,B and Figure 7A). The vertical variability highlighted a cyclic repetition of 2-6-m-thick calcrete profiles sandwiched in the Bekhme carbonates (Figures 4, 5 and 8 ) in the Spelek-Sulauk area. In the field, the calcrete profiles showed a strong bioerosion and moldic features related to biological activities (plants, ostracods, Thalassinoides, and other burrows; Figure 6C,F, Figure 7B,C and Figure 8). A lateral variability was locally observed in the Spelek section with non-hydrothermally brecciated rocks bound by the calcrete profile on one side and the Bekhme carbonates on the other (Figure 6A). The calcrete profile showed a sub-profile of lamination textures, including repeated white- and gray-banded textures, and constituted rounded cobble and pebble calcarenite deposits, which presumably referred to channel deposits and tidal signatures (Figure 6C,E). Moreover, the calcrete facies in Sulauk section started with a yellowish-green soft marly limestone and marl overlying a discontinuous irregular "erosional surface" (Figure 5A,B and Figure 6E). In the Spelek section, this surface was absent.

The stratigraphic record locally preserved V-shaped channelized structures 1-4 m wide and up to $3.5 \mathrm{~m}$ in thickness with internal cross-bedding that truncated the calcrete facies (Figure 5B). The filling was composed of small-scale cycles of 1.5 to $5 \mathrm{~cm}$ thickness (Figure 6C) with laminae of dark microbial mats alternating with thick (decimeters up to one meter) peloidal-bioclastic laminae (see Section 4.5). Such rhythmicity was reported in modern and ancient tidal-dominant environments and is related to slight sea-level variation [17-19] (see Figure 8). In places, the laminar facies were underlain by reworked carbonate cobbles and pebbles embedded in a mudstone groundmass with vertical bedding, which thins upward.

The study area exhibited other typical tidal signatures, such as ripples that washed out tidally (Figure 6D), cross-bedding deposits (Figure 6B), and common bioturbation activities (e.g., Thalassinoides, burrows, plant debris, worms, etc.) that were distributed randomly and sometimes vertically. A quick facies shift in the Sulauk section showed the transition of the calcrete facies to planar laminae (Figure 6C), with graded bedding, trace fossils, burrows, intraclasts, and ripple washed-out and floated cobbles and pebbles (Figures $4 \mathrm{~B}$ and $6 \mathrm{~B}-\mathrm{F}$ ). 

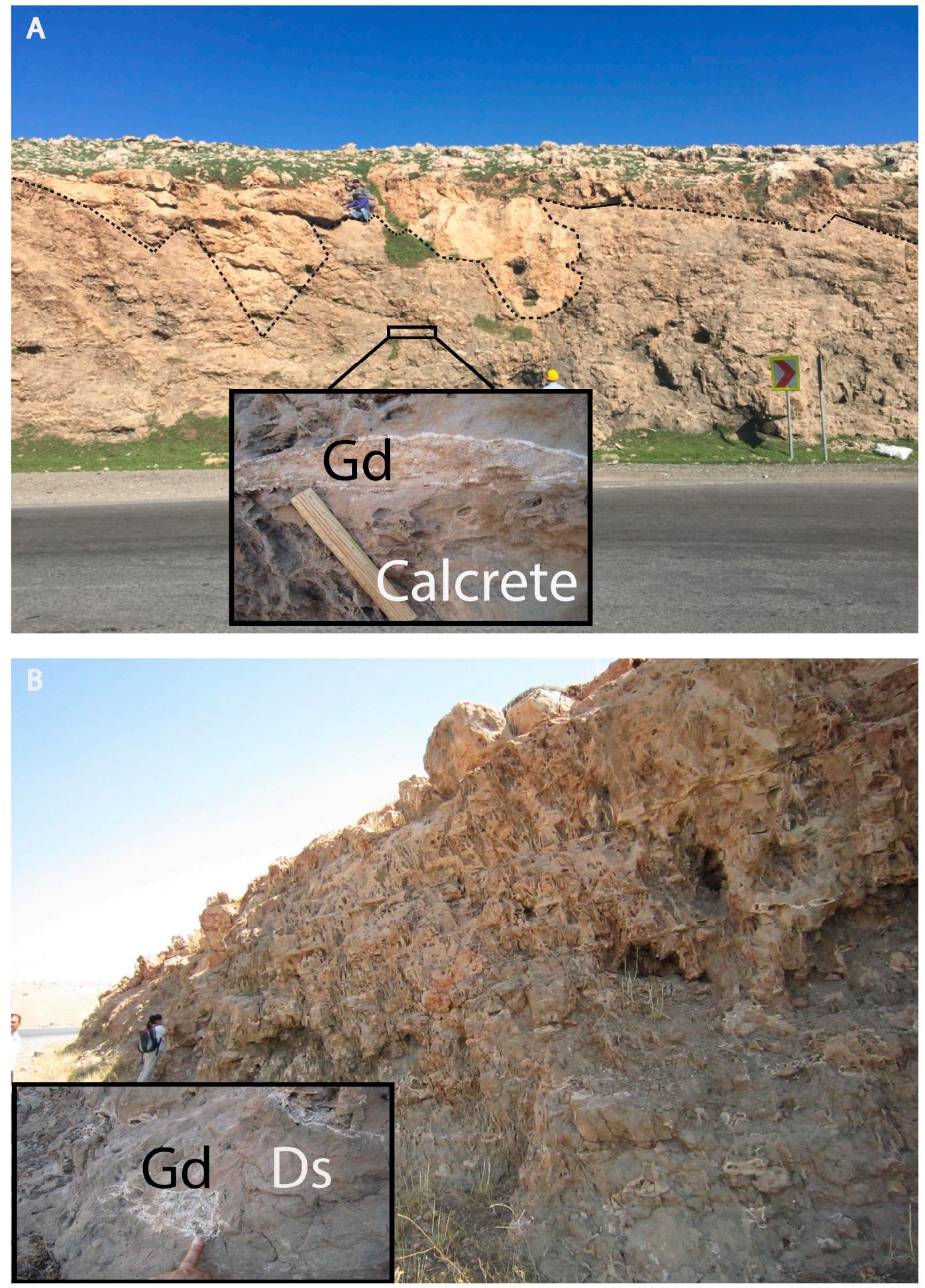

Figure 4. Spelek section. Photographs with inserts showing (A) calcrete profile displaying pronounced geodes (Gd) filled by saddle dolomite and blocky calcite arranged in multiple levels parallel to stratification, and reflecting the original bedding planes. The emplacement of the geodes (Gd) is interrupted by a yellowish facies in the Bekhme carbonates related to incised channel deposits cutting the original bedding planes (see the dashed line). Spelek section. The inserts show a typical single large geode with quasi-horizontal lower boundary tracing the original horizontal bedding. (B) Calcretization of the host limestone and matrix dolomite. Saddle dolomite and blocky calcite are mostly pronounced in the lower part of the outcrop exposing Bekhme Formation (Fm), consisting of saccharoidal dolomite (Ds). 

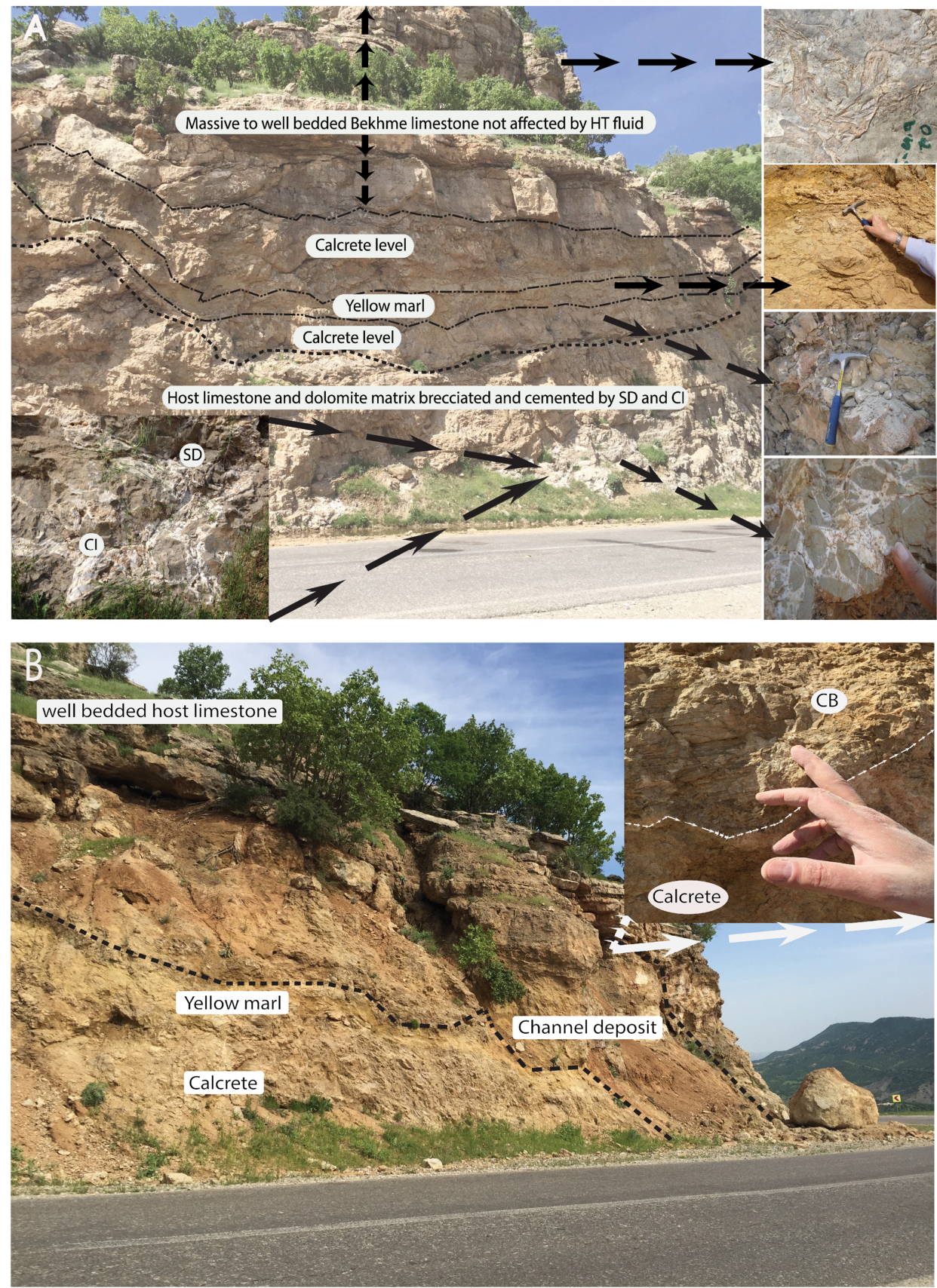

Figure 5. Spelek section. (A) Profile of the two calcrete levels. The profile shows interruption by a yellow marly horizon and interbedding within the well-bedded dolomitic limestone of Bekhme Fm. The basal part of the host limestone is brecciated (see the lower insert) by hydrothermal fluids and partly replaced by the calcrete level. The brecciated zone is cemented by saddle dolomite (SD on the picture) and blocky calcite (CI), and the brecciated fragments are mostly edge-shaped suggesting that the fracturing was consistent with hydrothermal fluid. The upper part of the section is partly influenced by hydrothermal (HT) fluids and overlies the calcrete level. The close-up of the lowermost right part shows that the altered gray colored dolomitic limestone in Bekhme Fm is driven by hydrostatic pressure of hot fluids leading to extensive fracturing and hydro-brecciated fragments, reflecting rapid changes in fluid pressure. Sulauk section. (B) Paleochannel deposit incised into the underlying calcrete profile. The upper right part of the photograph (white arrows) shows the cross-bedding (CB) in the channel. The cross-beds are gently inclined and predominantly composed of carbonate sand. The well-bedded Bekhme limestones directly overlie the channel deposits. Sulauk section. 

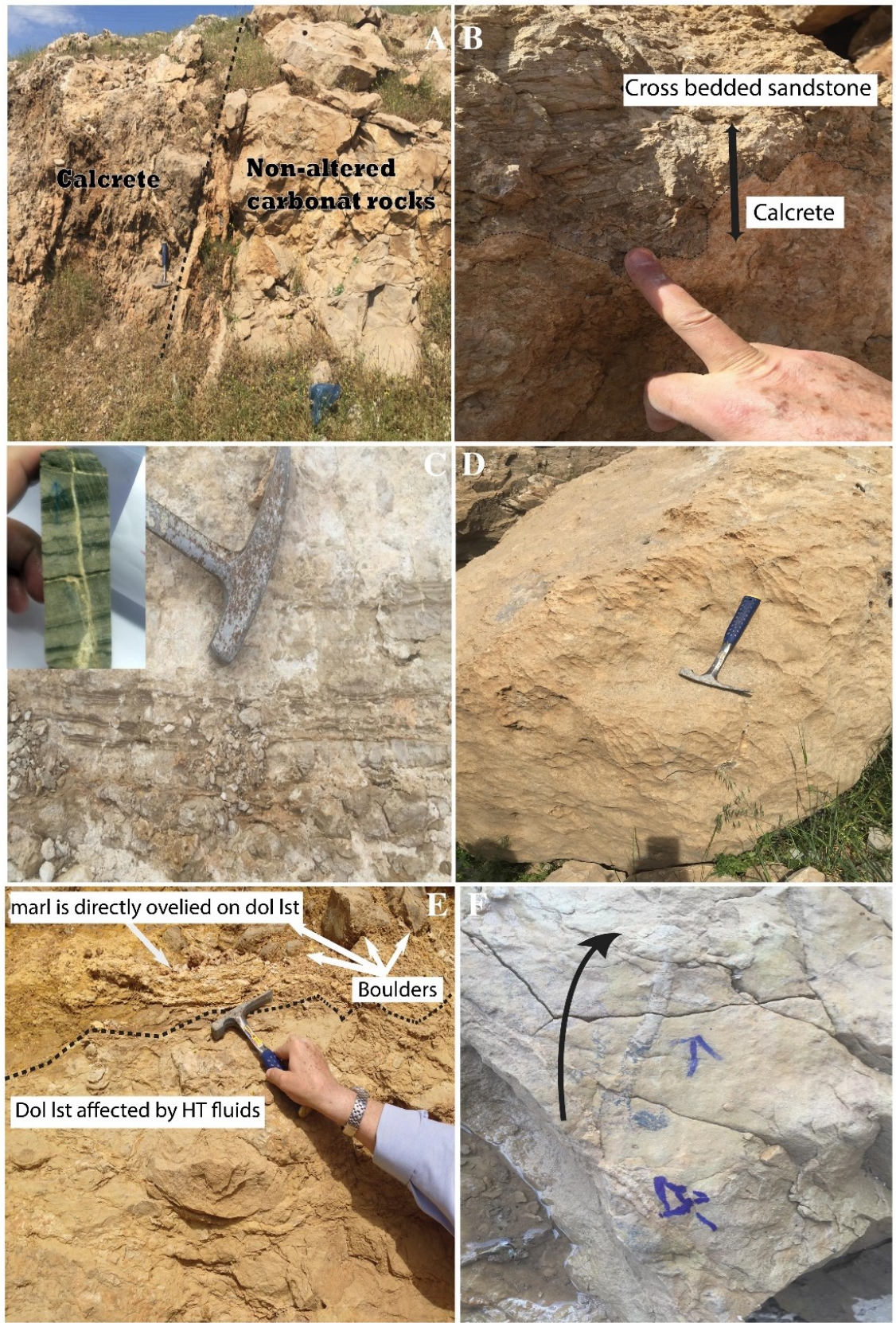

Figure 6. (A-F) Photographs of field and rock slabs showing the calcrete development and structures of tide-influenced in Bekhme Fm. (A) Abrupt contact between Bekhme Fm (right side) and the calcrete profile (left side) recording a subaerial exposure surface, probably due to tectonic uplifting. Spelek Section. (B) Cross-bedding of channel deposit overlying and incising the calcrete profile. The cross-beds are gently inclined and composed predominantly of a carbonate sand. Sulauk section. (C) Horizontal laminations with slightly undulating centimeter-thick dark-colored levels of microbial boundstone, where the lower most part is composed of cobble and pebble particles forming a fining upward thin sequence, with bioturbation on the upper left part. Sulauk section. (D) Rill-marks washed out by wind and water energy. Sulauk section. (E) Horizontal laminated crust superimposed on the upper part of Bekhme Formation, where large gray angular boulders are embedded in the softy ground mud. Sulauk section. (F) Biological activity on the surface of Bekhme Fm, where arrows point to a Thalassinoides burrow. Sulauk section. 

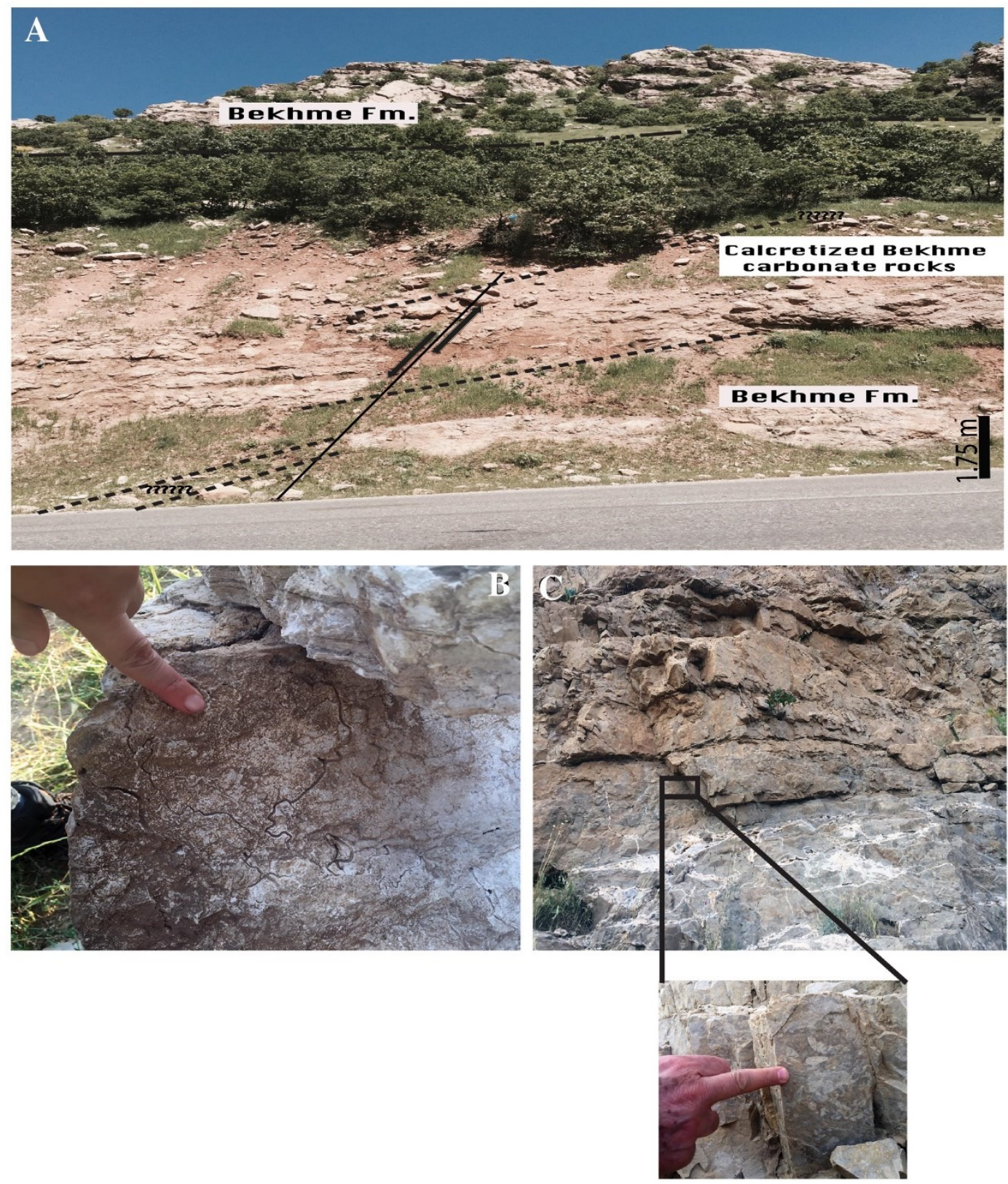

Figure 7. (A) Local fault slipping down the basal outcropped part of Bekhme carbonate and the calcrete level covered by the upper and lower Bekhme carbonate. Sulauk section. (B) Disturbed part, related to a burrowed zone in the muddy white dark laminated layers (see photograph $\mathrm{C}$ ), with intense bioturbation and low diversity of ichnofossils, indicating a tide-dominated channel. Sulauk section. (C) Hydrofracturing in the gray dolomitic limestone from the lower part of the photograph leading to the formation of fragments. The associated fractures and voids are filled by hydrothermal products (saddle dolomite, see text). Sulauk section. 


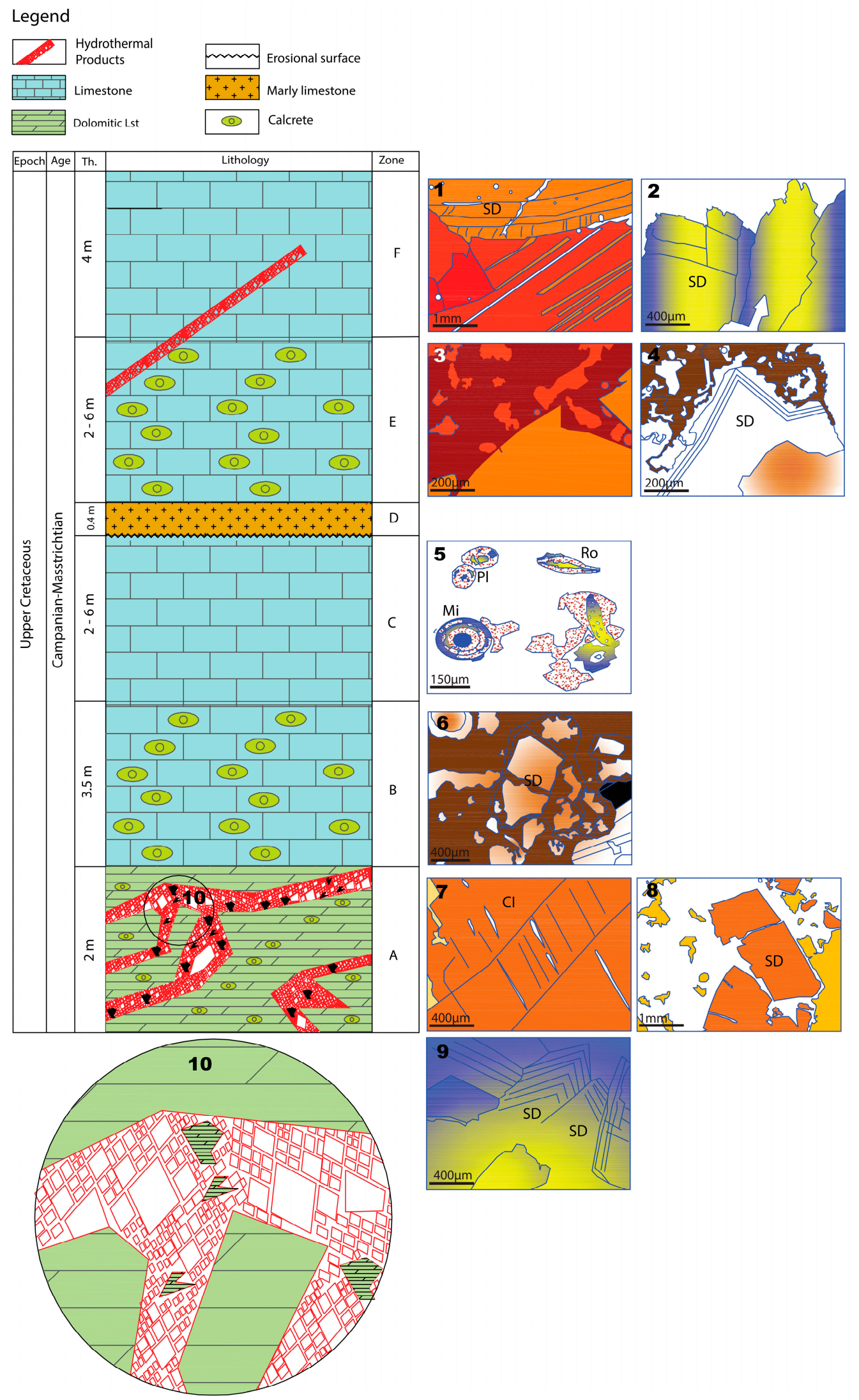

Figure 8. Litho-log of the Bekhme Formation from the Spelek-Sulauk area, and, next to each zone, the digitized microphotographs illustrating the significant alteration of HT and non-HT diagenesis on the carbonate rocks. The log shows the emergence (zones B and E) and submergence (zones C and F) of 
the host carbonate rocks. At least two generations of HT fluids paved their way along the weakness zones of the host rocks in zones A, E, and F. Note the enlarged part (No. 10) of the first generation of HT fluid (zone A), the so-called breccia, illustrating the floated, angular grains of the matrix dolomite that is cemented by saddle dolomite. Note another type of brecciation by pedogenic calcrete that caused an in situ fragmentation of the saddle and matrix dolomites (No. 3, 6, 8) and non-deposition period evidenced by marly bed (D). The HT cementation happened prior to the strong in situ brecciation of saddle dolomites (No. 3, 4, 8). Photomicrographs (No. 1, 2, 7, 9) illustrate unaltered HT products, while photo No. 4 shows the penetration of alveolar texture (the brown color on the left part) along the weakness joints of saddle crystal. The process of alveolar formation is illustrated in photo No. 6; the blue layers denote successive layers of dark micrite around broken dolomite and show a non-sequential process of coating, starting with an individual tube, followed by a combination of two tubes, until several adjacent tubes are bundled in an external micrite coat giving a quasi-concentric structure. $\mathrm{CI}=$ blocky calcite, $\mathrm{SD}=$ saddle dolomites, $\mathrm{Mi}=$ Miliolid, $\mathrm{Ro}=$ Rotalid, $\mathrm{Pl}=$ planktonic foraminifera (modified after Reference [23]).

\subsection{Petrography and Diagenesis}

\subsubsection{Reefal Boundstone and Bioclastic Packstone Facies or "Original Limestone"}

The boundstone facies was about $1 \mathrm{~m}$ thick and usually blanketed the upper part of the dolomitized rock. It consisted of a micrite matrix with abundant large rudists, undetermined bivalves, and a few miliolids. Rocks collected in this formation within the High Folded Zone and the Imbricated Zone belong to a complex reefal facies and played a significant role in paleoenvironmental change [20-22].

The bioclastic packstone facies was composed of fragments of rudists (Figure 5A) with benthic (miliolids and rotalids) and planktonic foraminifera. Ostracods, bivalves, and burrows represented a minor component in this microfacies. Secondary porosities in bioclasts, in places filled with quartz crystals, were present. Most of the rudists in the boundstone were well preserved, and no reworking was suggested. In contrast, they were broken and micritized in the packstone.

\subsubsection{Chertification and Replacive Silica}

Cryptocrystalline, fine-grained silica, forming centimeter-sized chert nodules and lenses (Figure 9A) with remnants of authigenic glauconite, was present. Globigerinids and globotruncanids were preserved from silicification and appeared to be floating in the siliceous groundmass (Figure 10B). These foraminifera were mixed in the rudist "reef". These microfaunae gave a Campanian-Maastrichtian age for the Bekhme Formation [10]. The intraparticular voids of the foraminifera were plugged by length-fast chalcedony and sometimes by cryptocrystalline quartz. Selective silicification of the globigerinids, globotruncanids, and rudists occurred during this diagenetic phase, and part of the pristine facies was eventually rather well preserved.

\subsubsection{Replacement Dolomite (DI)}

The first phase of replacive dolomite had a brown color, was fabric-selective, and displayed anhedral, non-planar, and small-sized rhombs $(\sim 50 \mu \mathrm{m}$; Figure $7 \mathrm{C})$. The dolomite occurred as a replacement product of the pristine facies, while wackestone fabric was still frequently preserved in the cores of the large-sized dolomite crystals. Remains of bitumen were observable between the rhombs (intercrystalline porosity). This fabric contained also a few glauconitic grains (around 5\%) along the dolomite crystal boundaries, in addition to amorphous iron oxides. Here, the glauconite belonged to the original marine sediments and was authigenic in origin. Reference [23] reported these authigenic minerals as a result of a slow precipitation in the open marine setting of Bekhme Formation that crops out close to the west of Erbil. 

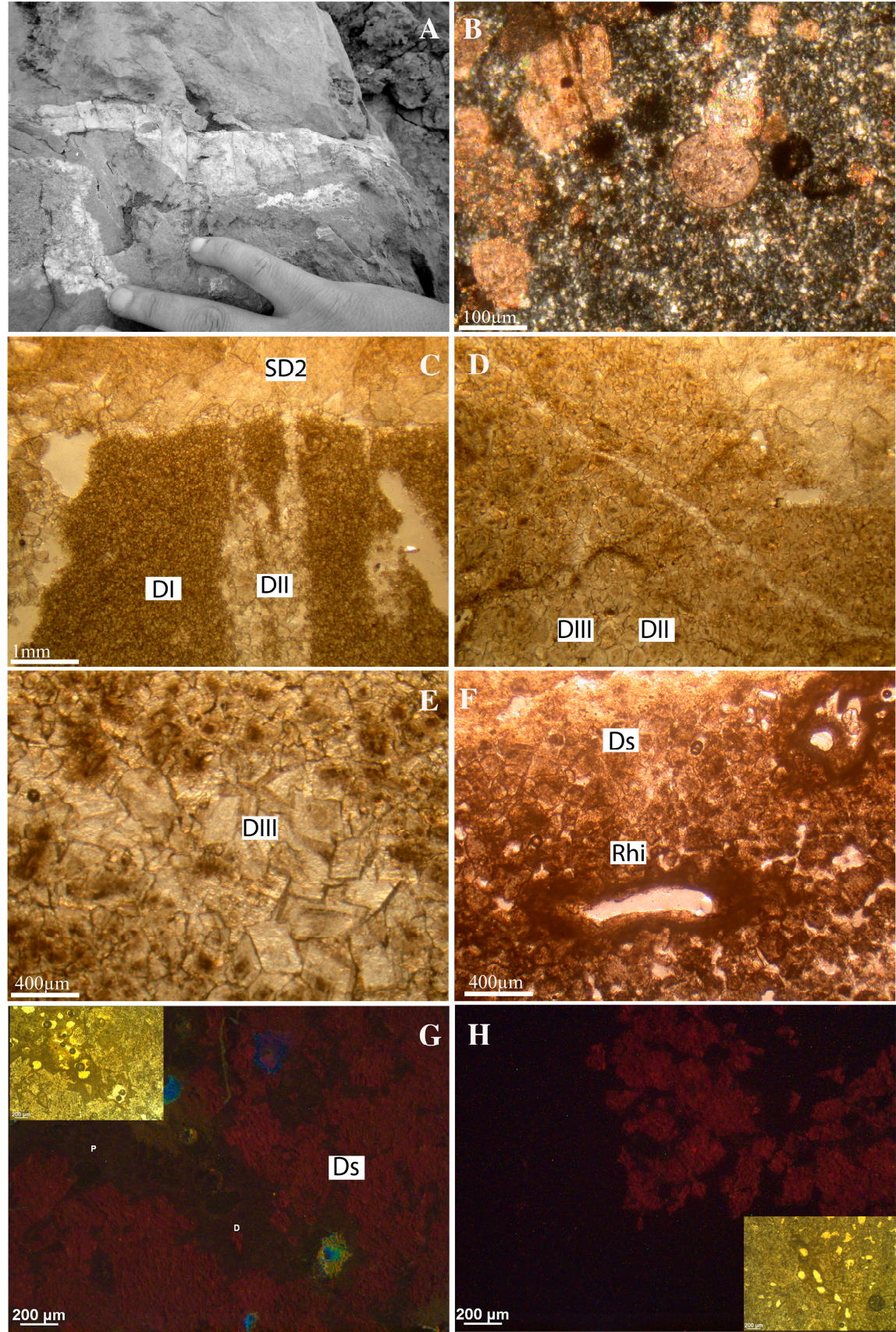

G H

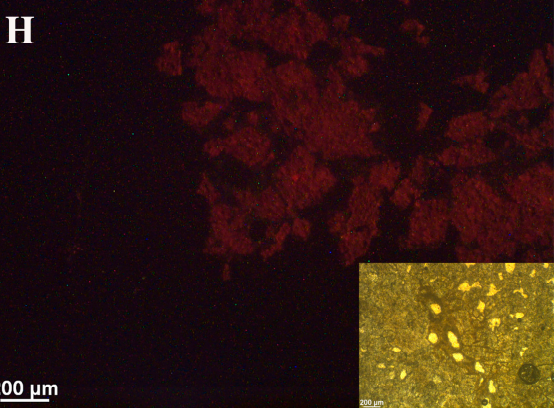

Figure 9. (A-H): Photomicrographs of dolomite and calcrete phases. (A) Calcrete profile displaying pronounced chert lenses and geode filled by saddle dolomite (lower left part). Spelek section. (B) Thin section, polarized light, same sample as Figure 3A; cryptocrystalline and fine-grained silica in a planktonic foraminiferal wackestone. Spelek section. (C) Thin section, plane light, brown facies representing the "replacement dolomite-DI", cross-cut by fracture filling with DII medium crystalline dolomite. The upper most part represents dirty saddle dolomite "SD2". Spelek section. (D) Thin section, plane light; transitional stage from DII (central part) to transparent dolomite DIII (toward leftmost lower part), suggesting that the replacement process is still functioning at this stage. Sulauk section. (E) Thin section, plane light; euhedral, transparent DIII filling a large void, where a few crystals are still shown as preserved traces of the former dolomites DII/DI, supporting the hypothesis of a replacement process during the early stage of diagenesis (see text). Sulauk section. (F) Thin section, plane light; the loose saccharoidal dolomite matrix (Ds) is significantly affected by the calcretization 
process; note the trace of a rhizoliths (Rhi) in the lower part of the picture. Spelek section. (G) Thin section, plane light and cathodoluminescence; saccharoidal dolomite Ds sharing the same physical properties and dull red luminescence as DII and DII. Ds formed probably as a result of paleostress from the previous "DII and DIII" phases during Late Cretaceous. The corroded relics of Ds inside the alveolar texture (AV, arrows) that have chocolate luminescence indicate that the calcrete postdated Ds. Spelek section. (H) Thin section, cathodoluminescence and plane light; dull red luminescence of Ds probably with corroded crystals floating inside non-luminescent calcrete products. Spelek section.
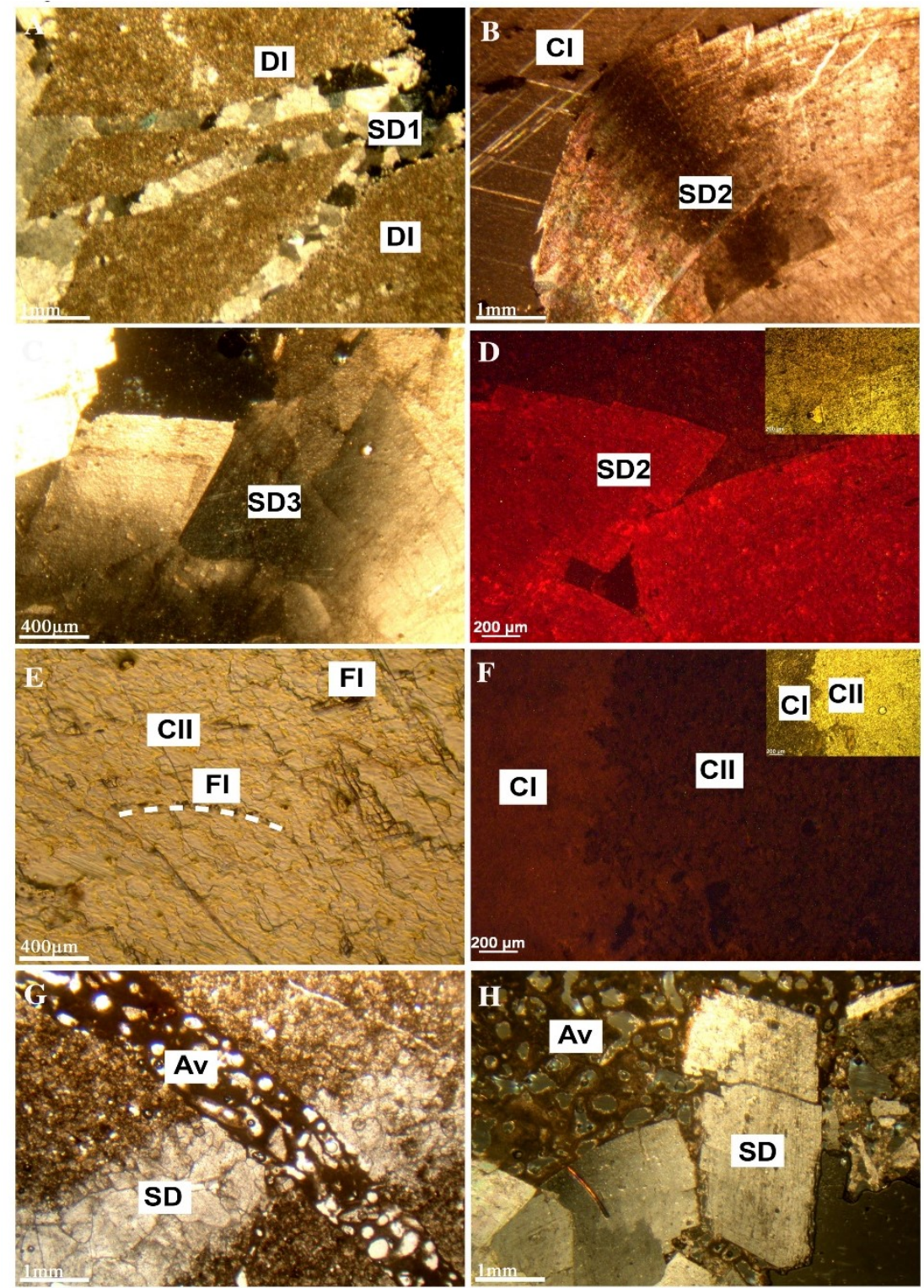

Figure 10. (A-H) Photomicrograph of hydrothermal saddle dolomites and calcites. (A) Thin section, polarized light, set of fractures filled by SD1, postdating the groundmass of DI. SD1 displays a unit extinction. Sulauk section. (B) Thin section, polarized light, typical wavy extinction and curved faces of saddle dolomite "SD2", from rightmost part, with corroded borders of blocky calcite CI on the left side. Sulauk section. (C) Thin section, polarized light; typical saddle dolomite SD3 as SD1 (Figure 3B), with different transparent colors and zoned areas along the crystal surface. Sulauk section. (D) Thin section, under CL; saddle dolomite SD2 displays red with thin layers of bright luminescence along the 
boundary of the crystals, indicating that fluids precipitating DI, DII, and DIII differed from those which precipitated saddle dolomites. Spelek section. (E) Thin section, plane light, two set cleavages of transparent calcite CII in center of photo with alignment of fluid inclusions and one isolated fluid inclusion (FI) in the uppermost right part. Sulauk section. (F) Thin section, two types of calcites, CI in left part and CII in right part, with the strongly corroded boundaries of $\mathrm{CI}$ indicating that CI predated $\mathrm{CII}$ in the paragenetic sequence. Note the two different luminescences under CL light, suggesting different depositional setting conditions for each fluid. Sulauk section. (G) Thin section, plane light; tubular/"alveolar" texture truncates both the previously formed dolomite matrix and the fracture-filled saddle dolomite cement. Spelek section. (H) Thin section, plane light; in situ bio-brecciation (see text) of transparent saddle dolomite, supporting the hypothesis that calcretization happened after Bekhme Fm was injected by hydrothermal fluids. Spelek section.

\subsubsection{Medium-Coarse Crystalline Dolomite (DII)}

Gray-brown medium-coarse (up to $300 \mu \mathrm{m}$ ) crystalline dolomite (Figure 9C) appeared as a replacive product of the DI matrix. The rhombs were anhedral-subhedral and interlayered with the tightly compacted DI matrix. Under the microscope, individual crystals showed a clear internal texture with micritic residues in the cores and free rims in the cortex (Figure 9D), with the crystals displaying a unit extinction under cross-polarized light.

The DII developed secondary porosities that were later filled by postdated saddle dolomite SD1 (see below). DII locally filled the primary intraparticular porosity of the planktonic foraminifera, and sometimes intersected DI fractures, filling at acute angles. Cathodoluminescence examination showed that DII had a very dull red to spotty red luminescence due to micritic-rich cores, while the outer zone or "rims" of some crystals showed only a red luminescence in the limpid zone.

\subsubsection{Transparent Dolomite (DIII)}

This type of dolomite was distinguished from the DI and DII by its crystal colors; it was transparent, planar, euhedral, and tetragonal, displaying sizes ranging between $100 \mu \mathrm{m}$ and $500 \mu \mathrm{m}$. The resulting fabrics were mostly non-selective and rarely selective. The latter were characterized by thick free rims around clusters of the "DII" rhombs growing as syntaxial overgrowths. This led to sharp contacts with the DII rhombs. As a consequence, DIII could represent a replacement product from DI and DII (Figure 9D,E). Unlike the selective "DI, DII", non-selective crystals commonly precipitated in the intercrystalline pores without leaving any former traces; thus, most of this type of dolomite might have been precipitated as a cement. Since there were no authigenic glauconite remains within DIII, this could probably denote that DIII precipitated as cement and did not replace DII or DI.

CL revealed that DIII had a similar dull red luminescence and texture to DI and DII. In addition, transparent dolomite exhibited uniform extinction under cross-polarized light, and DIII usually filled the remaining secondary porosities.

\subsubsection{Saccharoidal Dolomite (Ds)}

A saccharoidal cloudy dolomite (Ds) occurred as dark brown and densely packed, ranging in size from $50 \mu \mathrm{m}$ to $400 \mu \mathrm{m}$. It formed a typical powder in the hand specimen due to a soft and friable matrix. This dolomite exhibited biological structures (algae and fungi; see Section 4.6) with longitudinal tubes cross-cutting the crystals (Figure 9F), reflecting that this dolomite was influenced by calcrete products during subaerial exposure in a later stage (discussed below). As we see later, these biological components affected the late dolomitization phases (SD2 and SD3).

Saccharoidal dolomite was pervasive, around half a meter in thickness, in the lower part of the Spelek profile. Its selective fabric, as observed under a microscope, shared the same petro-physical properties (shapes, sizes, CL) as DII/DIII, and was probably formed as a result of intensive stress due 
to fault brecciation affecting DI and DII in the Spelek section. Ds showed a dull red luminescence with rare spots of bright red luminescence (Figure 9G,H).

\subsubsection{Medium-Sized Saddle Dolomite (SD1)}

This dolomite consisted of medium-sized ( $200 \mu \mathrm{m}$ up to $650 \mu \mathrm{m})$, beige-colored, euhedral, planar to non-planar crystals. The crystals showed radial arrangements cementing and plugging the newly formed fractures, partially lining their walls (Figure 10A); they also developed in geodes similar to the geodic dolomites reported by Reference [24]. In the field, these geodes formed horizontal and sub-horizontal levels parallel to the bedding planes in the Spelek and Sulauk profiles. These geodes were not systematically filled by SD1 only, as other cementation processes (dolomite and calcite) occurred (discussed below). This type of dolomite was always associated with the next generations of saddle dolomites (see below), and SD1 always adopted the basal space of fractures and geodes.

\subsubsection{Dirty and Milky Saddle Dolomites (SD2 and SD3)}

Coarse crystalline dirty saddle (SD2) and milky saddle dolomites (SD3) usually precipitated in open cavities and fractures. They cross-cut DII, with SD3 and SD2 filling the geodes, whereas the remaining space of the geodes was later filled by subsequent CI and CII cements (see below).

SD2 was composed of coarse euhedral, non-planar to planar crystals, with sizes growing up to a few $\mathrm{mm}$, displaying a typical sweeping extinction (Figure 10B). SD3 was composed of euhedral and non-planar crystals, which are coarser than those of SD2, with sizes ranging from a few millimeters to around $1 \mathrm{~cm}$. The crystals displayed strongly curved faces (SD3 in Figure 10C), they were zoned or unzoned with common fluid inclusions giving a dirty aspect under the microscope, and they exhibited two sets of cleavages. In some fractures, SD2 and SD3 dolomites showed corrosion features with precipitation of a blocky calcitic overgrowth (discussed below).

Under CL, SD2 and SD3 were characterized by mottled and zoned textures with a bright red luminescence along the crystal cortices and a red luminescence toward their cores (Figure 10D).

\subsubsection{White Calcite CI and Transparent Calcite CII}

$\mathrm{CI}$ and $\mathrm{CII}$ calcites formed following the precipitation of the SDI, SD2, SD3, and the cherty nodules from the pristine facies. The $\mathrm{CI}$ calcite was recognized in the Spelek section filling the remaining voids and open fractures related to the geodes, while, in the Sulauk section, CI calcite was commonly observed in narrow fractures and large "voids" along brecciated zones formed by hydraulic mechanisms as a consequence of the hydrothermal and tectonic activities. The late CII calcite displayed euhedral, planar, blocky crystals with sizes exceeding one centimeter and abundant fluid inclusions (Figures 9 and 10E). They also showed two sets of cleavage, sometimes with corrosion structures, and displayed unit extinction under polarized light. Generally, CII occurred in the remaining porosities associated with the geodes, and it was more developed in the Spelek section than in the Sulauk section.

Both calcite cements (CI and $\mathrm{CII}$ ) were characterized by uniform textures and dull orange and dull red luminescence, respectively, under CL (Figure 10F).

\subsection{Degrading Mechanism and Sparmicritization in Calcrete}

Calcrete is a near-surface facies of terrestrial accumulation of predominantly calcium carbonate, which occurs in a variety of forms from powdery to nodular or highly indurated, as a result of cementation, as well as displacive and replacive introduction of calcium carbonate into soil, bedrock, and sediments [25-27]. It is dominant in semi-arid and arid conditions [28].

The calcrete profile (about $2 \mathrm{~m}$ thick, up to $6 \mathrm{~m}$ thick) in our study area was observed in all three sections and occurred intermittently in the precursor limestones of Bekhme Fm. The limestones were highly developed in the lower and middle parts of the studied sections, and they were not arranged orderly from top to base but randomly distributed "laterally and horizontally" within this profile. 
In the field, the Spelek calcrete showed a strong lateral variation. The main characteristic of this level was, therefore, the heterogeneity, well apparent in the field.

\subsection{Petrography of the Calcrete Level}

The diagenetic phase in the Spelek-Sulauk area came after the formation of the dark-brown structures representing the calcrete products. These consisted of four textures which were as follows: (i) rounded, oval, and cylindrical voids (alveolar texture), (ii) pisolites and laminar texture (hard crust), (iii) transitional horizon, and (iv) chalky texture.

The calcrete profiles in the Spelek-Sulauk area occurred in the lowermost-middlemost portions of Bekhme Formation as a massive layer (around $6 \mathrm{~m}$ thick). The petro-fabric was studied under polarized and cathodoluminescence microscopes, as described below.

\subsubsection{Type 1: Alveolar Horizon}

The alveolar horizon was brown to dark brown and characterized by millimeter-sized micritic septal bordering plant roots and rootlets (Figure 10G). These were composed of spherical, cylindrical to elliptical, and sometimes irregular "fenestrae". Root traces displayed frequently hollow shapes, and occasionally contained preexisting dolomite crystals. These "fenestrae" were interconnected by a latticework of micritic products playing as bridge interconnections. This texture was mostly developed in the dolomite matrix and cut across all former crystals related to the former high-temperature phases. As a result, the alveolar microstructures led to a bio-brecciation of the saddle dolomites and blocky calcites, as a result of the plant activities and probably the microbial mediation (Figure 10H).

In some cases, the alveolar texture showed a tubular and cylindrical fenestral microfabric, usually developed along the weakness zones and cleavages of the different saddle dolomites and the blocky calcites (Figure 8). As a consequence, the facies was brecciated, and the former dolomites and calcites were floating in the micritic groundmass. Brecciated fragments created angular to sub-rounded edges of the former saddle dolomite and blocky calcite cements. These fenestral microstructures were filled with recycled coarse-grained saddle dolomitic and blocky calcitic crystals, which were later degraded into a fine-grained micrite/or dolocrete (Figure 10G). Many of these fenestral microstructures appeared straight or as curved tubes in thin sections, which revealed a previous filling with former cements that were later removed or dissolved. These cement-filled cylindrical shapes were coated by a dark micrite. Usually, a few coated crystals or coated hollows were repeatedly surrounded or encrusted by micro-laminated structures. These textures were well represented and accounted for approximately $40 \%$ of the total volume in the studied area.

These cylindrical shapes were coated by successive layers of dark micrite, followed by a combination of two tubes, until several adjacent tubes were bundled in a final external micrite coat forming a quasi-concentric structure (Figure 10H).

These particular micro-fabrics crossed and replaced SD2, SD3, and CI with precipitation of a new phase consisting of bladed and fibrous needle-like cements (Figure 11A). These were associated with recycling and re-precipitation of the former dolomite matrices (DI, DII, DII/Ds), SD2, and SD3, and they always displayed a physical distortion with deformation of the crystal shapes. Figures $10 \mathrm{H}$ and $11 \mathrm{~A}$ show algal boring along calcite cement within the alveolar texture, accompanied by laminar horizons. 

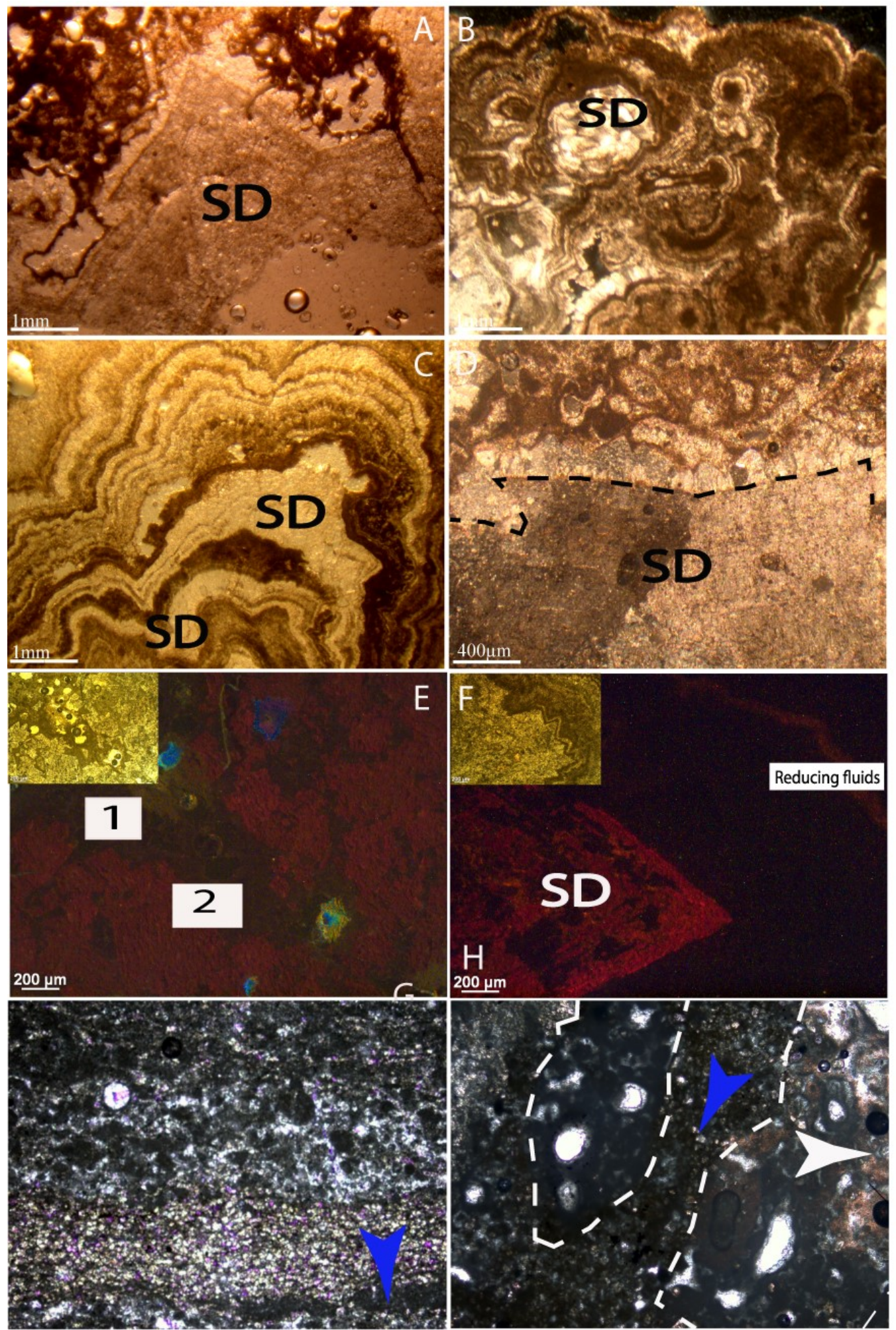

Figure 11. (A-H) Photomicrographs of calcrete products and tidal features. (A) Thin section, plane light; dirty saddle dolomite crystal (SD) penetrated by the alveolar texture (Av), followed by bladed cementation (white arrows) due to meteoric/vadose fluids (see text). Spelek section. (B) Thin section, plane polarized light; showing the pisolitic texture, where pisoids are spherical or irregular, and their nuclei are composed of saddle dolomite (SD) of former hydrothermal products (see text). Concentric laminated layers enclose the pisoids, and the space between the layers is filled by fibrous cement. Middle lower part of photo shows a clear bladed cement (BL) along the laminated layer. Spelek section. 
(C) Thin section, plane light; alteration of saddle dolomite (SD) to laminar crust inside a geode. The precipitated cement between the laminated layers frequently represents the recycled saddle dolomite (SD). The upper cement binding these layers could be originated by another fluid during the calcretization stage as shown under CL in (F). (D) Thin section, plane polarized light; the dashed line illustrates the transitional horizon from saddle dolomites (SD) to tubular and cylindrical fenestral microfabrics as a result of the alteration of the pedogenic calcrete (Av). Wavy extinction of saddle dolomite is followed by precipitation of bladed cement (see black arrows) along the saddle outlines. Spelek section. (E) Thin section, CL and plane light; showing a paragenetic sequence between 1 (calcrete) and 2 (dolomite), probably related to another fluid that penetrated the previous dolomite formation. Spelek section. (F) Thin section, CL and plane light, pisoids surrounded by concentric laminar layers. CL: Pisoid nuclei in the right part gave a red with spotted bright red luminescence represent the former saddle dolomite crystals; note the dissolved area inside the SD crystal. Paragenetically saddle crystal predates the thick dull chocolate luminescence, followed by thin layer of bright orange luminescence. (G) Thin section, plane light; laminar bindstone (arrow) in the lowermost part of photograph. Close-up yellow dolomite crystals, which appear aligned in parallel rows, with respect to microbial mat direction (same sample from Figure 6C). The uppermost part illustrates bioclastic peloidal packstone/grainstone, with the violet color showing the pore spaces between peloids filled by silica. Sulauk section. (H) Thin section, plane light; two reworked intraclasts (dashed line) embedded in microbial mats (blue arrow). Note the right one; the nuclei of oncoid intraclasts consist of wood relicts (Figure 7C—polished sample). Sulauk section.

\subsubsection{Type 2: Pisolitic and Laminar Horizons}

The pisolitic and laminar horizons varied from dark brown to light brown in color, and contained small peloids in the groundmass composed of macrocrystalline dolomites and calcites. The size of pisoids varied between 0.5 and $2 \mathrm{~mm}$, the thickness of the laminar horizons was up to $400 \mu \mathrm{m}$, and these features (peloids and laminae) commonly occurred together in the middle part of the calcrete level (Figure 11B). The above-described horizons constituted up to $5 \%$ of the total calcrete/dolocrete volume of the altered Spelek section.

In the hand specimen, the pisoids and laminae occurred in geodes where coarse saddle dolomite and blocky calcite precipitated. The nuclei of the pisoids potentially consisted of silty and sandy clasts, and peloids were coated intensively by a dark-brown micrite (sparmicritization, see Reference [29]); however, in our study, the nuclei mostly consisted of fragments of former saddle dolomite (Figure 11B-F) and blocky calcite cements. Their shapes varied from spherical to polygonal, oval, and irregular, the latter resulting from several coalescent carbonate nuclei surrounded by concentric laminated layers (Figure 11C). The laminar textures were similar to the ones reported in the Eyam Limestone and southern Europe from Lower Carboniferous, Upper Jurassic, and Lower Cretaceous [30,31], where they were connected to subaerial exposure and calcified root-mats [31]. In contrast to our case, these authors did not find any features of biogenic structures such as calcified organic filaments (see Section 4.6) and alveolar septal textures.

The micropores and cavities between concentric laminae were filled by fibrous-radiaxal, bothryoidal, or bladed cements (Figure 11C). Under polarized microscope, the pisoids and laminar textures displayed a wavy extinction and followed the same geometry of the former saddle dolomites (recycling of SD). Furthermore, under cathodoluminescence, the pisoid nuclei displaying red luminescence represented a preserved pseudomorph of corroded and dissolved saddle dolomite crystal (Figure 11B).

The laminar and pisolitic facies occurred in the void space, resulting in the alteration of the high-temperature minerals precipitated in these voids, in contrast to the alveolar facies developed in the former dolomitic groundmasses which were transformed into partially to totally powdery/dusty carbonates. 


\subsubsection{Types 3: Transitional Horizon}

The transitional horizon was observed in most of the lower part of the Spelek-Sulauk calcrete profiles. This horizon was underlain by unaltered or partially altered carbonate of Bekhme Formation (Figure 11D). This horizon was vertically and horizontally characterized by abrupt laminated and irregular micritic stringers (sparmicritization) with unaltered or partially altered hydrothermal saddle dolomites and blocky calcites of the host sediment. In places, micritic stringers were associated with alveolar textures, mainly in the coarse saddle dolomites and calcites, leading to a breccia with large and angular fragments.

Similar stringers were reported by Reference [32] in many Quaternary and Devonian pedogenic calcretes which were subaerially exposed. The tubular and cylindrical hollow features (discussed above) were also present in the transitional zone.

\subsubsection{Type 4: Chalky Textures}

The chalky textures, common in the calcrete level, were frequently associated with the transitional horizon. They were characterized by grayish white to cream-colored fine-grained and soft dolomites, sometimes slightly indurated with aggregates forming nodular horizons interlayered with soft horizons of a "brecciated host limestone". The aggregates were coated by large concentric laminar textures containing a few micritic filaments. This horizon was placed between the transitional and alveolar horizons, but were also potentially absent in many locations, and, unlike the transitional horizon, it was not well defined and not obvious microscopically.

Cathodoluminescence images of calcrete displayed distinctive colors for both micrite and needle-like calcite cements in the form of dull chocolate and chocolate luminescence (Figure 11E), and non-luminescence in places.

\subsection{Microfacies of the Paleo-Channel}

The calcrete facies in the Spelek-Sulauk area were cut by a 1.5-m-thick sedimentary fill of weakly lithified, thinly to thickly bedded alternations of white bioclastic peloidal packstone/grainstone and black microbial mat bindstone. These facies displayed planar laminations of sub-millimeter to several centimeters thick (Figures 6C and 11G). Below the laminar level was a 70-cm-thick bed of pebbles and cobbles floating in a muddy groundmass. The components had ellipsoidal and rounded shapes (Figure 6C).

At least three microfacies were recognized within these planar laminations, discussed below.

\subsubsection{Microfacies 1: Microbial Bindstone}

This microfacies consisted of centimeter-thick sheet-like, thin, flat, and dark lamina (Figure 11G). The undulated structures seen in a few layers were similar to the laminoid structures seen in Reference [33] and were related to microbial mats. Most of the laminar bindstone textures were well preserved, although some were occluded by subhedral yellowish dolomitic crystals oriented along the microbial mat. These contained organic matter and dichotomous filaments (Figure 11G). Importantly, the dolomite crystals appeared to be floating within the organic mass with no cementing material, but they were rather enveloped by the organic mass (Figure 11H). Similar instances were reported [34] from the Lower Carboniferous in the north of France. Bioclasts as ghost structures associated with rare peloids were also observed. Clays were present as stacks aligned horizontally and parallel to the microbial mats.

\subsubsection{Microfacies 2: Bioclastic Peloidal Packstone/Grainstone}

This microfacies consisted of thicker white planar layers that varied widely from a few millimeters to several decimeters in thickness (Figure 6C). Among the bioclasts, ostracods were predominant, associated with a few gastropods, miliolids, and burrows of worms. Blocky, bladed, and meniscus 
cements frequently filled the intragranular pores of most of the bioclasts. The remaining space between the peloids and bioclasts was occupied by secondary silica, which sometimes filled the intrabioclastic porosity (Figure 11G—see violet color). Abundant rounded and elongate peloids with variable sizes were present.

\subsubsection{Microfacies 3: Intraclastic Peloidal Grainstone and Mudstone}

This microfacies contained abundant ostracods and miliolids, and was commonly burrowed. Locally large (millimeter-sized) sub-spherical oncoids were reworked as intraclasts (Figure 11H). The oncoids were characterized by dark coated peloids or "peloids-supported oncoids". In the hand specimen, large centimeter-sized oncoids were observed. They were surrounded by thin laminated layers and, in places, contained large nuclei of wood relicts. The intraclasts were not well sorted, locally reaching up to $3 \mathrm{~cm}$ in size; they are rounded/subrounded and commonly float in the channel deposits. This facies was widespread within the planar laminations and varied in thickness from millimeters to centimeters. Peloids were mostly rounded and they dominated, constituting up to $70 \%$ of the sediment; they were well sorted. Other components were fine- to medium-sized quartz crystals, constituting sometimes up to $45 \%$ of the sediment. Small-sized blocky and bladed cements usually filled the remaining porosities. Sometimes, these intraclasts displayed intense muddy coated grains which wrapped them together.

\subsection{Microbial Diagenesis}

\subsubsection{Microbial Forms}

The studied rock samples showed ubiquitous colonization and alteration by several types of endolithic microbial forms that displayed morphologies consistent with filamentous fungi (Figure 12A-E), bacteria forms (Figure 13A,C,F), and an oval spindle shape of probable single-celled algae/cyanobacteria (Figure 13F). They ranged in size from micron-sized bacteria $(0.5-2 \mu \mathrm{m})$ to single-celled cyanobacteria $(\sim 60 \mu \mathrm{m})$ and filaments of various sizes. This interaction with the rock substrates produced particular diagenetic features, as reported later.

i. Fungi

The fungi were present as hyphae within the carbonate substrate pore space, either penetrating or perforating the substrate (Figure 12C). In several instances, flattened hyphae were observed deeply embedded in the matrix structure of the substrate (Figure 12C,D) giving evidence of their fossilized nature. Many of these hyphae showed dense mineral encrustations in the form of crystallites, typical of fungi interacting with the carbonate substrates and cycling of $\mathrm{Ca}^{2+}$ and $\mathrm{Mg}^{2+}$ from the substrates, as well as their re-precipitation as $\mathrm{Ca}$ - or Mg-oxalates within the substrates and/or as encrustations on fungal hyphae [35-39]. Traces of extracellular polymeric substances (EPS) were also visible (Figure 13E).

\section{ii. Algal Forms}

Oval spindle-shaped single cells reminiscent of algal cells morphologies were frequently observed within the matrix of the calcrete (Figure 13F). The mineralized cells appeared well embedded within the calcrete matrix and surfaces, showing submicron mineral encrustations (Figure 13F). In one instance, similar cell morphology with a much larger size $(\sim 60 \mu \mathrm{m})$ was observed. The cell appeared densely encrusted with mineral crystals and embedded in the substrate colonized by fungal filaments. The cell showed mineralized attachments that could be cautiously interpreted as flagella. 


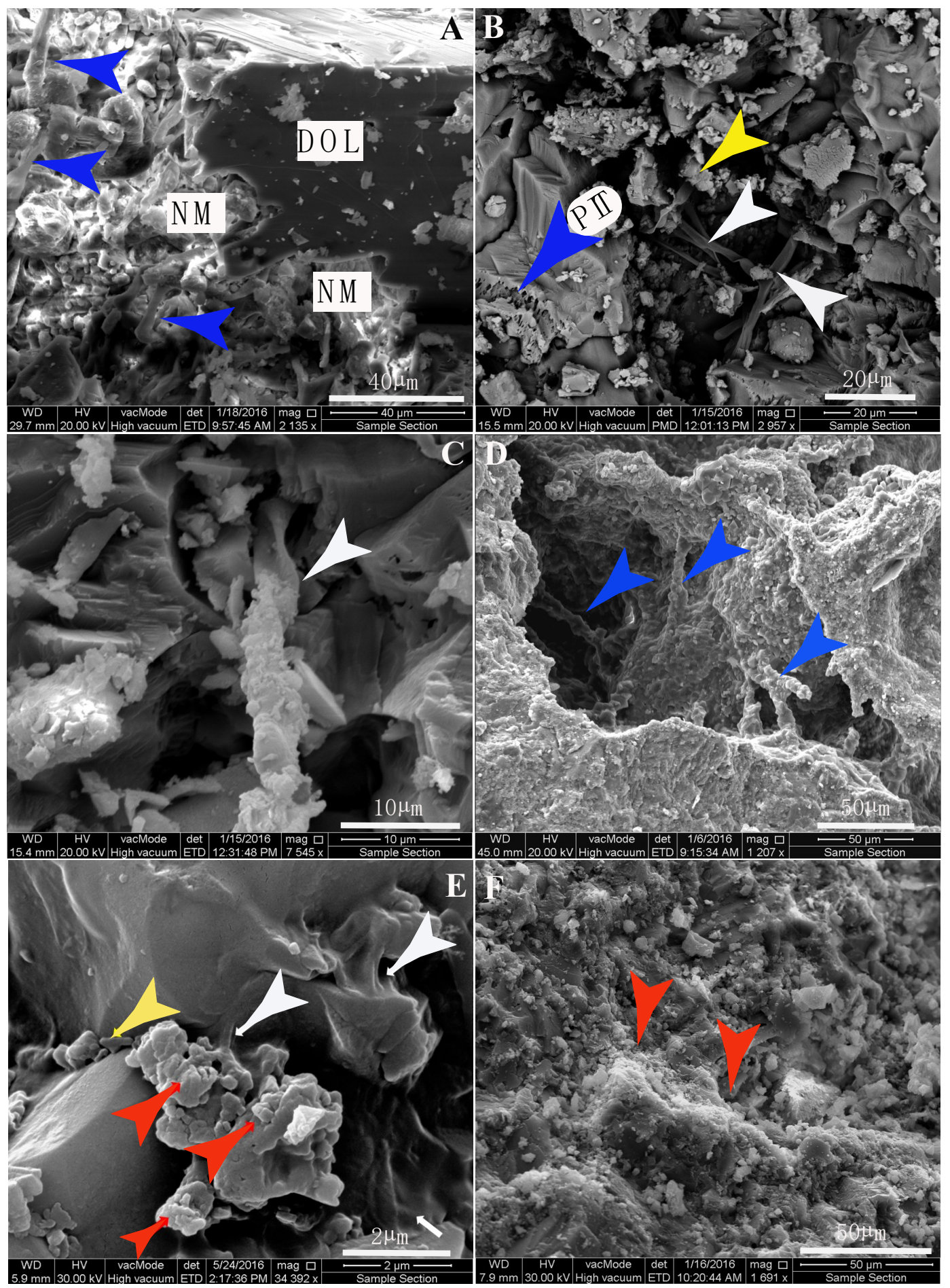

Figure 12. (A-F) SEM micrographs illustrating microbial diagenetic process on preexisting mineral surfaces. Spelek section. (A) Dissolution of original substrate and microbially (arrows) precipitated neominerals (NM). The microbial attack caused the strong dissolution of the dolomite crystal (DOL). Microbial filaments (arrows) are visible within the altered substrate. (B) The central part of the micrograph shows calcified dichotomous filament (white arrows), probably of fungal origin. Pitted dissolution (PIT) is also observed associated with deposition of neominerals (yellow arrow) indicating the microbially alteration of Bekhme Fm. (C) Fungal hyphae (arrow) perforating the original substrate, showing extensive encrustation with biomineral, indicating the important role of microorganisms in the calcretization process (see text). (D) Dissolution of the original substrate by root and rootlets of plants, resulting in the development of the alveolar texture. Wall bridging of such pores is related to the 
growth of microbial filaments (arrows), leading to beta fabrics in the calcrete (see text). The filaments show typical calcification and encrustation by bio-minerals. (E) A microbial biofilm showing newly formed micrite-size biominerals (red arrows), and microbial forms (yellow arrow) all embedded in extracellular polymeric substance (EPS) biofilm. The EPS is clearly attached to the original carbonate crystals, all of which make a microbial microcosm where biomineralization occurs and new micrite is formed (F) Micritization and de-micritization processes on the original carbonate substrate showing the alteration of dolomite crystal boundaries and deposition of micrite size of neominerals (arrows). The original micrite is not visible, consumed by microbial activities.

\subsubsection{Bacterial Forms}

Bacterial forms, mostly coccoidal, were quasi-abundant in all studied samples, which understated their role in the diagenesis of carbonate substrates. A significant characteristic of bacterial-mineral interaction was related to the bacterial adherence to mineral surfaces (Figure 13F), with diagenetic consequences well established in literature regarding the alteration of the substrates [40]. One biosignature resulting from this adherence and interaction was the bacterial cell encrustation with biominerals, probably calcitic, and the probable microporosity produced by bacterial pitting of the mineral surface (Figure 13A,C).

\subsubsection{Dissolution}

The carbonate calcrete displayed multi-level microbially altered substrates and crystals at various stages of dissolution and neomineral deposition, sometimes in advanced stages (Figure 12A), giving rise to pseudo-stratification. As a result, the neominerals were microbially deposited on the original crystals and substrates. The crystal boundaries of the former dolomitic facies were preferentially dissolved, leading to deep dissolution patterns, frequently filled by new minerals either inside the crystals or in the larger dissolution space (Figure 12A). In a few cases, the mineral surfaces were heavily pitted owing to preferential dissolution (Figure 12B). Fungal hyphae encrusted by micron-sized neominerals are observed perforating the original carbonate substrate (Figure 12C).

The alveolar textures exhibited ubiquitous dissolution features (Figure 12D), which subsequently became filled and/or lined with a micron-sized calcitic micrite covering the inner walls of the cavities following the decomposition and removal of organic matter associated with the plant roots and rootlets.

Specific microbial dissolution of the original substrates and reprecipitation of rhombohedral neominerals suggest that they were probably dolomitic in nature. Figure $6 \mathrm{E}$ displays very tiny rods and sub-spherical forms clustering around the remnants of the original carbonate crystals similar to those reported by Reference [41].

\subsubsection{Micritization and De-Micritization}

SEM imaging showed micrite precipitation and a micritization process induced by microbial activity. The neominerals ( $\sim 1 \mu \mathrm{m}$ in size) were precipitated in the porous space or on the edges of carbonate crystals (Figure 12F). The process could have been generated either by the dissolution of the original micrite (de-micritization) along the carbonate crystal boundaries or directly on the mineral surfaces [42] (Figure 11F). The microbial de-micritization and micritization processes on the calcrete constituted a new cementing phase (Figure 12F).

De-micritization, as presented here, is a process through which the original micritic material of the carbonate substrate is removed by fungal dissolution, which leaves the much larger dolomite or calcite crystals as isolated islands surrounded by vacant space, at least in the early stages of dissolution [42]. Figure 13A,B show a de-micritized zone on an original substrate where the fine-grained material (cement) filling the space between the carbonate grains was removed, leaving in place the more resistant crystals (mainly dolomite). Subsequently, the voids created through this de-micritization process were refilled partially or totally by the precipitates of the newly formed carbonate crystals. These replaced 
the old material that was consumed through the microbial dissolution and chemical element uptake. The crystal size of the new biomineral infill ranged between 5 and $25 \mu \mathrm{m}$. The micrite-sized new biominerals were probably composed of Ca-oxalate and possibly Mg-oxalates with both Ca and $\mathrm{Mg}$ cycled from the carbonate substrate. According to Reference [43], it is only through further diagenesis that this new biogenic micrite was transformed into true cryptocrystalline calcite. The current use of the term micritization is, thus, in anticipation of such diagenetic transformation.

\subsubsection{Cementation}

Cementation (or re-cementation) of carbonate grains in the microbially de-micritized calcretes was related to the new micritization process (Figure 9F). The new cement was distinguished from the surrounding minerals by its pile-up texture and its lighter color. Grain-to-grain bridging, suture lines, and crystal boundaries fillings were all observed features of microbially induced cementation (Figures $12 \mathrm{D}$ and $13 \mathrm{~A})$.

\subsubsection{Replacement}

Microbial interaction with the carbonate substrate produced diagenetic replacements of the original crystals by new minerals. Figure 13A shows a dolomitic crystal undergoing a replacement initiated by the partial dissolution and precipitation of very a fine micron-sized calcite. The edges and/or boundaries as the planes of weakness were more susceptible to bacterial attacks than other parts (faces) in terms of dissolution and replacement.

\subsubsection{Grain-to-Grain and Wall Bridging}

Bridging of the dissolved pores in the alveolar textures was frequently observed. Mineral-encrusting algae and encrusting fungal hyphae were similar in shape and size to crystals that lined the inner walls of the pores (Figure 12D). On the other hand, grain-to-grain bridging was observed between dolomite crystals by newly precipitated biominerals (up to $6 \mu \mathrm{m}$ ), connecting the dolomite crystals and filling the secondary porosities.

The micron-sized new calcite cementing the dolomite crystals on its margins produced mineralized microstructures linking the dolomite crystals [42,44] (Figure 11A). Special attention was paid to micro-porosities associated with these mineral surfaces. Porous surfaces on carbonate minerals could have been generated by microbial activity [45]. The inferred microbial diagenetic sequence involved dissolution of dolomite crystals, followed by the precipitation of a new carbonate phase with different color contrasts in the SEM analysis (Figure 13A).

\subsubsection{Open-Space Filling, Porosity, Permeability, and Grains Size}

Open-space filling was observed in the pores of the calcrete, as well as in the dissolved pore spaces (inter- and intragranular), produced by microbial dissolution and de-micritization, where extensive deposition of biominerals occurred (Figure 13B). The filling of the intergranular porosity occurred as a fringing cement lining the inner contour of the pore, as well as partially littering the pore (Figure 13C). Secondary intragranular porosity created by microbial attacks on the crystals was filled by the biominerals produced by the fungi. Figures 12A and 13B show a dolomite crystal with a secondary intragranular porosity that was refilled with newly precipitated biominerals. The biominerals were micron-sized $(<1 \mu \mathrm{m})$ and clustered in the pore $(>10 \mu \mathrm{m})$. In contrast to the tiny prismatic biominerals precipitated on the surface of the same dolomite crystal, these biominerals were much larger $(2-5 \mu \mathrm{m})$ and were rhombic in shape.

Fungal filaments enhanced the dissolution of carbonate minerals and penetrated their surface, leaving a semi-spherical void (around $10 \mu \mathrm{m}$ ). It resulted, in some cases, in a well-preserved filament encrusted by very thin neominerals (Figure 11C). It was not possible to quantify the impact of fungal dissolution on both porosity and permeability, but visual evaluation suggests that the increase might have been important (Figure 13B,D). 

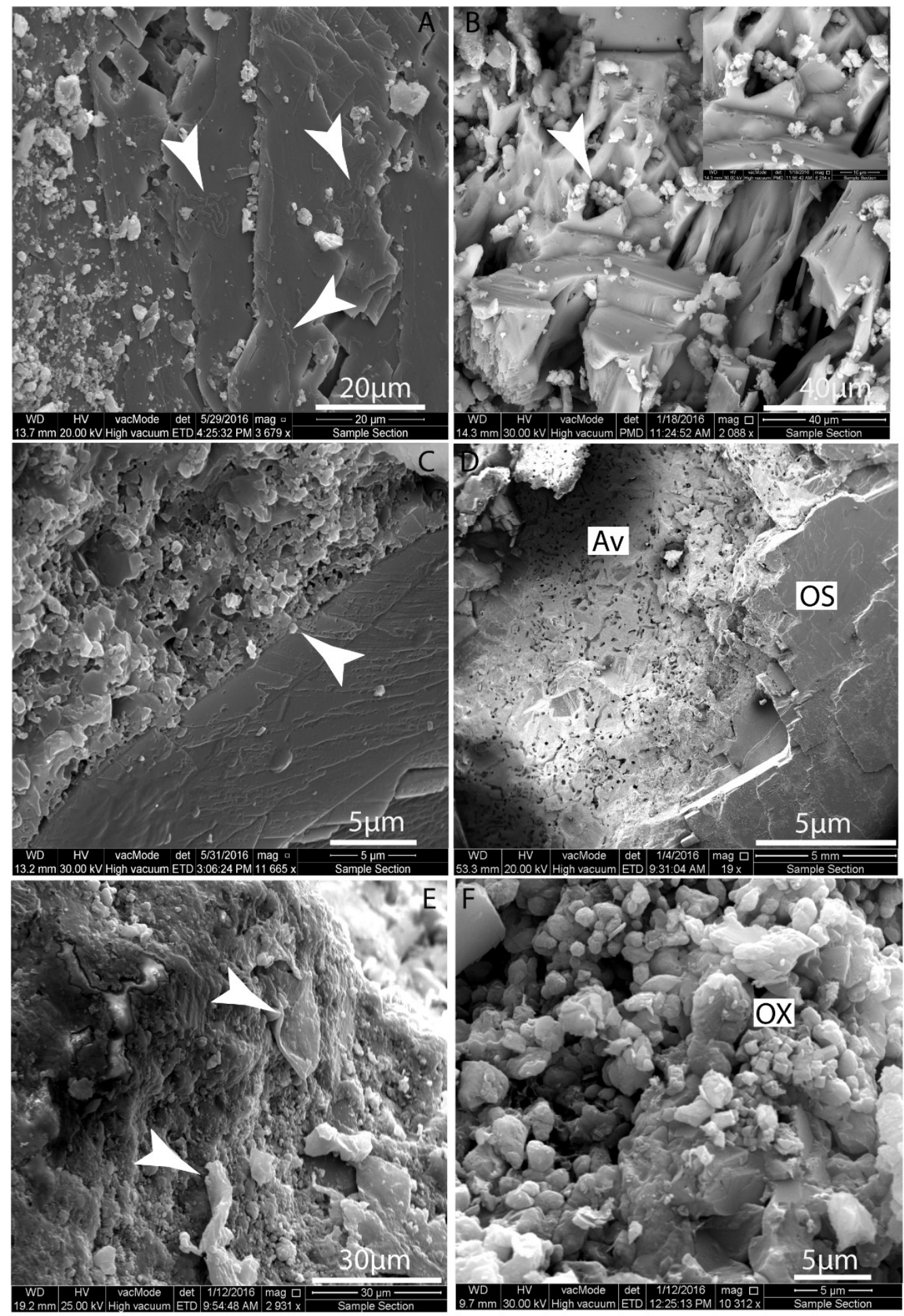

Figure 13. (A-F) SEM photomicrographs showing biological influences on the original carbonate substrate. (A) Coccoidal rod-shaped bacteria arranged in chain form and tightly linked (arrows), attached to the original surface. Sua.9. Sulauk section. (B) New biominerals, probably pseudomorphs of $\mathrm{Ca} / \mathrm{Mg}$ oxalate minerals, precipitated inside dissolved cavities between unaltered substrate (see arrow and enlarged part in the right upper part). Sp.7. Spelek section. (C) The boundary between dissolved and partly dissolved original substrate is clearly shown (arrow). The right part shows the traces of bacterial reaction to the surface of the substrate, while the left part mostly shows the dissolved the substrate. Sua.9. Sulauk section. (D) The distinction between soil products (Av) and the original 
surface of the carbonate (OS) is shown. The in situ brecciation of root and rootlets of the plant giving an alveolar texture (Av) indicates the role of biogenic diagenesis in the area. Sp.11. Spelek section. (E) Traces of extracellular polymeric substances (EPS, see arrows). Sp.11. Spelek section. (F) Probable single cells of microbial forms with recycled carbonate substrate, producing oxalate minerals (OX). Sp.7. Spelek section.

\subsection{O-C Isotopes}

The oxygen and carbon isotopic compositions of the studied carbonates are compiled in Table 1 and Figure 14. The Cretaceous $\delta^{18} \mathrm{O}_{\mathrm{VPDB}}$ and $\delta^{13} \mathrm{C}_{\mathrm{VPDB}}$ values of the primary marine carbonates, estimated by References [46-48], varied respectively between $+0.8 \%$ o and $-4.0 \%$ o and between $+1.8 \%$ o and $+2.7 \%$. The $\delta^{18} \mathrm{O}_{\mathrm{VPDB}}$ and $\delta^{18} \mathrm{C}_{\mathrm{VPDB}}$ of the host limestone of Bekhme Formation were approximately $-5.1 \%$ and $1.1 \%$, respectively [23]. The $\delta^{18} \mathrm{O}_{\mathrm{VPDB}}$ and $\delta^{13} \mathrm{C}_{\mathrm{VPDB}}$ values of the calcrete products ranged between $-17.8 \%$ o and $-6.6 \%$ o (average (av.) $=-8.0 \%$ o, $n=10$ ) and between $2.5 \%$ o and $-9.6 \%$ o (av. $-2.7 \%$, $n=10)$, tending to be lower than those of the marine limestones. The $\delta^{13} \mathrm{C}_{\mathrm{VPDB}}$ values of the calcretized saddle dolomite samples $(n=7)$ displayed a large negative shift (as low as $-7.0 \%$ o) compared to the host limestone rocks. The $\delta^{18} \mathrm{O}_{\mathrm{VPDB}}$ and $\delta^{13} \mathrm{C}_{\mathrm{VPDB}}$ of the paleo-channel/tidal deposits that crossed the calcrete levels in the Sulauk section varied between $-6.5 \%$ ond $-8.1 \%$ o (av. $=-7.0 \%$ o, $n=12$ ) and between $+1.7 \%$ o and $-8.6 \%$ o (av. $=-2.4 \%, n=12$ ), respectively. The $\delta^{18} \mathrm{O}_{\mathrm{VPDB}}$ and $\delta^{13} C_{\text {VPDB }}$ isotope values of tidal deposit samples frequently matched or were close to those isotopic values from saddle dolomites diagenetically altered by the calcrete formation. Calcretes and calcretized saddle dolomites recorded a wide range of $\delta^{13} \mathrm{C}_{\mathrm{VPDB}}$ values from $-7.4 \%$ o to $-6.3 \%$ o (av. $=6.9 \%$ o, $n=6$ ) (Figure 14), while the $\delta^{18} \mathrm{O}_{\mathrm{VPDB}}$ values varied from $-8.7 \%$ o to $+1.7 \%$ o (av. $=-6.9 \%$ o, $n=6$ ).

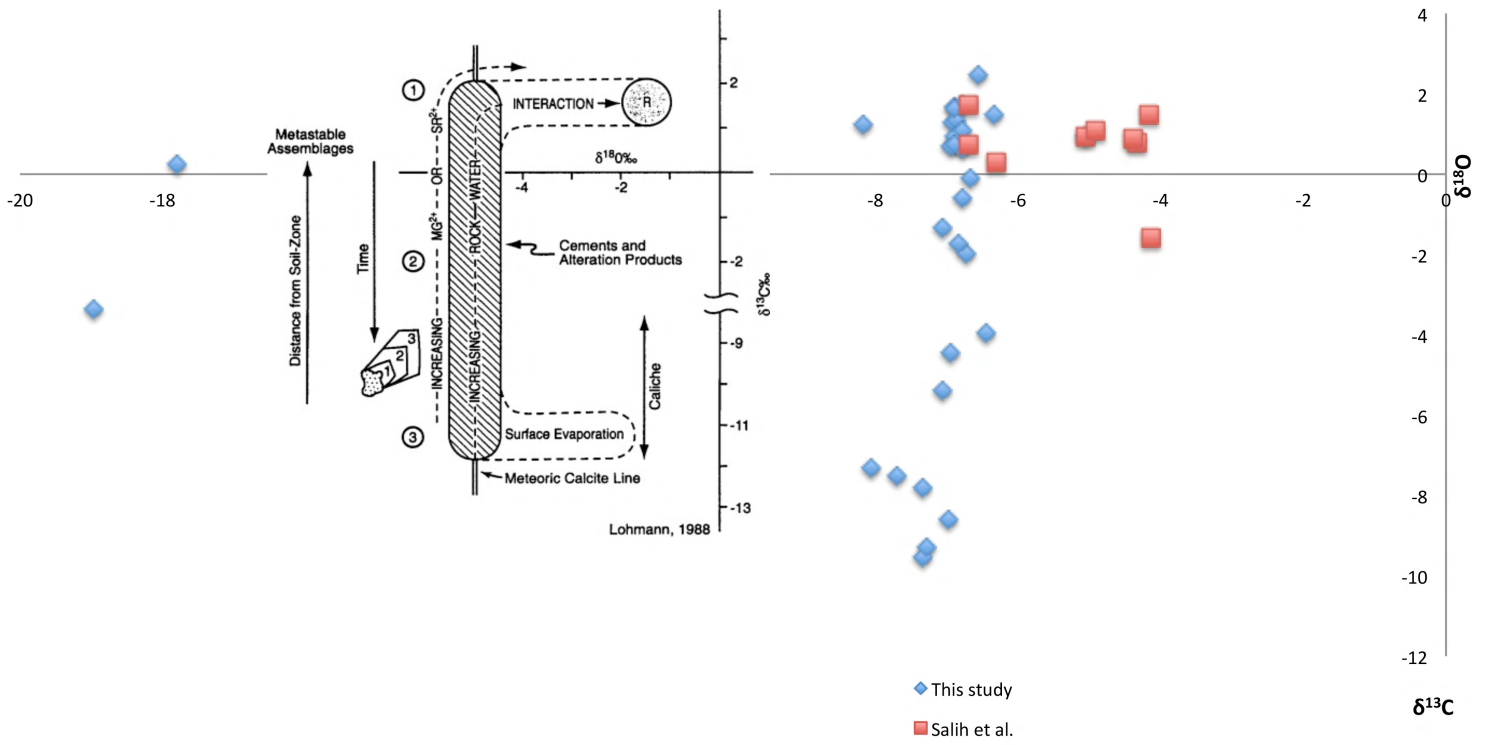

Figure 14. $\delta^{18} \mathrm{O}_{\mathrm{VPDB}}-\delta^{13} \mathrm{C}_{\mathrm{VPDB}}$ isotope data of Bekhme Formation from Spelek-Sulauk area (blue points). Variable data of carbon compared to oxygen isotope, and the overlapping of recent values, with the Lohmann model emphasizing that the low-temperature fluid (calcrete) had a role in the diagenesis of the host limestone of the studied section. 
Table 1. $\delta^{18} \mathrm{O}_{\mathrm{VPDB}}$ and $\delta^{13} \mathrm{C}_{\mathrm{VPDB}}$ isotopic composition values (\%o), where Cal = calcrete, $\mathrm{DI}=$ matrix dolomite, $\mathrm{CI}=$ blocky calcite, $\mathrm{SD} 1=$ saddle dolomite, and $\mathrm{TD}=$ tidal deposits.

\begin{tabular}{|c|c|c|c|}
\hline Sample No. & Phase & $\delta^{13} \mathrm{C}$ & $\delta^{18} \mathrm{O}$ \\
\hline Sp.3 & Cal & -0.61 & -6.78 \\
\hline Sp.3 & Chert nodules & 0.68 & -6.96 \\
\hline SP.5 & Cal & -9.56 & -7.34 \\
\hline SP.8 & Cal & -5.4 & -7.05 \\
\hline SP.11 & Cal & -0.12 & -6.66 \\
\hline SP12 & Chert nodules & 0.64 & -6.78 \\
\hline SP13 & Cal & 2.45 & -6.55 \\
\hline SP.3 & Cal & -1.34 & -7.06 \\
\hline Sua.42 & DI & 1.21 & -8.17 \\
\hline SP.5 & Cal & -9.27 & -7.28 \\
\hline Sua.45 & DI & 0.96 & -6.88 \\
\hline Sua.43 & Cal & 0.96 & -5.07 \\
\hline SP.6 & CI & -3.36 & -18.98 \\
\hline SP.31 & Cal & -1.98 & -6.73 \\
\hline SP.16 & Cal & 1.69 & -6.88 \\
\hline SP.8 & Cal & -7.81 & -7.33 \\
\hline SP.4 & SD1 Calcretized & 1.46 & -6.33 \\
\hline SP.30 & Cal & 0.25 & -17.8 \\
\hline Sua.46 & TD & 1.28 & -6.91 \\
\hline Sua.47 & $\mathrm{TD}$ & 1.32 & -6.86 \\
\hline Sua.48 & TD & 0.75 & -6.88 \\
\hline Sua.49 & TD & -1.72 & -6.84 \\
\hline Sua.50 & $\mathrm{TD}$ & 1.1 & -6.77 \\
\hline Sua.51 & TD & -3.98 & -6.45 \\
\hline Sua.52 & TD & -8.62 & -6.97 \\
\hline Sua.53 & TD & -7.34 & -8.06 \\
\hline Sua.54 & TD & -7.5 & -7.71 \\
\hline Sua.55 & TD & 1.73 & -6.77 \\
\hline SP.29 & TD & 1.65 & -6.88 \\
\hline Sua.56 & TD & -4.44 & -6.94 \\
\hline
\end{tabular}

\section{Discussion and Interpretation}

\subsection{Origin of Geodes/Fracture-Filling Carbonate Minerals and Origin of Calcrete}

Three different types of saddle dolomites (SD1, SD2, and SD3) and two types of blocky calcites (CI and CII) occurred in the study area. The first phase of saddle dolomite (SD1) was mostly associated with the second generation of SD2 or SD3. The aggrading transition to coarser crystal size inside the geodes and fractures (from SD1 to SD2), having characteristics of curved faces and wavy extinction under optical microscope (Figure 9B,C), suggest a key indicator of hot fluids with a temperature higher than $50{ }^{\circ} \mathrm{C}$ [49-51]. The geodes formed when the fluids meandered their paths through the various weakness zones as the fractures, the cleavages, and the joints (Figure 8). The brecciated and floated angular grain of matrix dolomites, which were cemented by saddle dolomites and blocky calcites, suggests that the hydrostatic pressure of hot fluids led to an extensive fracturing and hydro-brecciated fragments (Figure 8), reflecting rapid changes in fluid pressure. The almost emplacement of bedding-aligned geodes interrupted a new deposition of unaltered host limestone of Bekhme Fm (Figure 5), signaling a new post-hydrothermal influx fluid. Moreover, the saddle dolomites in Bekhme Formation had similar stable isotopic composition and originated from hot $\left(81-115^{\circ} \mathrm{C}\right)$ basinal $\mathrm{NaCl}-\mathrm{MgCl}_{2}-\mathrm{H}_{2} \mathrm{O}$ brines with salinities of $18-22 \mathrm{wt} . \% \mathrm{NaCl}$ equivalent [11].

The occurrence of two cycles of calcrete profile sandwiched between host limestones of Bekhme Formation, and the significant thickness of calcrete products that showed abundant biological activity (Figures $6 \mathrm{~F}$ and $7 \mathrm{~B}, \mathrm{C}$ ) probably suggest that the Harir and Safin Basins developed during rising and 
falling of sea water, and not due to other factors such as vertical aggradation of deposits by river or channels deposits [17]. Nevertheless, the calcrete profile showed a sub-profile of lamination textures, including repeated white- and gray-banded textures, and constituted rounded cobble and pebble calcarenite deposits, which presumably referred to channel deposits and a tidal-influenced channel during the rise and fall of the sea level (e.g., Reference [52]) (Figure 6C,E).

The surface contact morphology between the calcrete body and the unaltered Bekhme limestone strongly suggests a possible incised paleochannel where the continuity of the original bedding planes was interrupted (Figure 5B). This facies change and the geometry setting indicate that the chronology of HT fluid influx and calcretization events was coeval with the depositional age of Bekhme Formation (Figures $4 \mathrm{~A}$ and $5 \mathrm{~A}$ ).

The increase in $\delta^{18} \mathrm{O}_{\mathrm{VPDB}}$ and $\delta^{13} \mathrm{C}_{\mathrm{VPDB}}$ depletion in the carbonate samples compared to the marine host limetone signified either (i) a progressive heating of the fluids that re-channelized the carbonate rocks [53] or (ii) formation under meteoric water influences. Invariable $\delta^{18} \mathrm{O}_{\mathrm{VPDB}}$ and variable $\delta^{13} C_{\text {VPDB }}$ values followed an inverted-J pattern or "curve" along a meteoric calcite line [51] (see Figure 14). These explanations invoke that the organic matter and decomposed roots of plants were consistent with intensive microbial activities, which influenced or "altered" the original host limestone and HT products (Figure 11). Therefore, a meteoric water source was the most conceivable source for the $\delta^{13} \mathrm{C}_{\mathrm{VPDB}}-\delta^{18} \mathrm{O}_{\mathrm{VPDB}}$ depleted carbonate cements, as late diagenetic calcrete products were well documented in our series with the Lohmann model (Figure 14)

The development of Harir-Safin anticlines was linked to the Zagros Mountains during opening and closure of the Neo-Tethys Ocean. During Cretaceous and Tertiary times, the predominate platform with lateral carbonate facies changed, and the hiatus was mainly related to sea-level changes and distant geodynamic events [54]. Lateral compression can increase the deformation of stratigraphic succession in the same way as vertical and horizontal movements of basement blocks through compaction [14]. Folding deformation was considered here to be likely the cause of the fracture system in Bekhme Formation during hydrothermal fluid migration. Reference [9] related the formation of void spaces/cavities to tectonic deformation regional events during Zagros Orogeny. Several authors concluded that the hydrothermal fluids are structurally controlled by fault and tectonic activities such as lateral compression and vertical stress [55-58]. The hydrostatically brecciated rocks, which occupied the lower part of Sulauk profile ( 2 m), cemented by saddle dolomites and blocky calcites (Figures $5 \mathrm{~A}$ and 8 ), indicate that the fracturing was contemporaneous with the hydrothermal fluids. Similar cases were reported by, e.g., References $[49,59,60]$.

Later on, the hydrothermally produced dolomites and calcites at the base of the $\sim 6-\mathrm{m}$ Spelek section were totally calcretized (see below; Figure 5A,B). The origin of calcretes in ancient strata was widely documented in ancient rocks [61-64]. Two dominant microfabric patterns were suggested for the calcrete origin: (i) non-pedogenic alpha fabric and (ii) pedogenic beta fabric [65].

Alpha fabrics are distinguished by abiotic features, which include desiccation cracks, shrinkage features, and nodules [65-67]. On the other hand, the biologically formed beta fabrics are dominated by rhizoliths, alveolar septal structures, calcified filaments, and grains coated by micritic layers $[27,67,68]$. Microbial activities (e.g., dissolution, replacement, and bridging of the dissolved pores) and microbially produced minerals played a key role in the alteration of the original carbonate substrates, most probably related to the roots and rootlets inside plants cavities (porosities) (Figures 12A and 13A-C). Pedogenic fungi are known to form fibrous needle-like calcite cement and diagenetic carbonates $[67,69]$, in addition to the formation of micritic cements [27]. Through subaerial exposure and break in sedimentation rates, numerous paleocalcrete products, particularly of biogenic sources, were formed [70-72].

The SEM images showed ubiquitous colonizing endolithic fungal, bacterial, and possible algal forms. Many of them displayed neomineral encrustation on their surfaces (Figure 12A). The dissolution of original substrate and the precipitation of abundant neominerals between and inside the carbonate grains highlighted the wide contribution of microbes in the development of pedogenic calcrete (Figure 13A). The microbial role in the dissolution process was highlighted by numerous visible 
microbial forms in the altered parts of the substrates that often form a dissolution front (Figure 13A) [42]. The microbial diagenesis was considered as persuasive evidence for the pedogenic calcrete nature. Moreover, the meteoric vadose waters during subaerial conditions could have played an additional role in the diagenesis process (Figure 13). These features were clearly established in the literature as of pedogenic origin $[27,73]$. In particular, the role of fungi as decomposers around the root and rootlets of plants within the soil profile and the related alveolar septal structures were also documented in various pedogenic soil morphologies [74].

Our microbial diagenetic associations in the studied area suggest that the calcrete formed in the Bekhme Formation originated predominantly from "beta fabrics". Several consecutive observations support this pedogenic origin. Firstly, the bio-brecciation, which produced the alveolar microstructures, also fragmented the former HT saddle dolomites and blocky calcites (Figure 10G,H). As the brecciated fragments were mostly angular, both host rocks and HT minerals of the Bekhme Formation underwent an "in situ alteration". Secondly, the pisoliths were always accompanied by millimeter-thick laminar textures interconnected by fibrous calcite cements (Figure 11B,C). Thirdly, the presence of nodular chalky deposits and numerous coated grains were used as a evidence of subaerial vadose conditions due to organo-mineral interaction [75]. Furthermore, microbial alteration on the original substrate developed a wide spectrum of diagenetic features: dissolution, micritization, cementation and re-cementation, replacement, grain-to-grain and wall bridging, and open-space fillings. All these characteristics support an in situ, pedogenic alteration during subaerial exposure. Additionally, three non-HT calcretized dolomitic samples in the Spelek section displayed negative $\delta^{18} \mathrm{O}_{\mathrm{VPDB}}$ values (Figure 14) similar to those discussed in the previous saddle dolomites, but they showed variable $\delta^{13} \mathrm{C}_{\mathrm{VPDB}}$ values toward very negative values $(-9.6 \%$ o for the lowest value). These data indicate that the meteoric water, which caused the calcretization of the former dolomite, was recharged through the soil profile.

The isotopic composition of the pedogenic carbonates is different from the non-pedogenic groundwater carbonates, as pedogenesis proceeds toward an isotopic equilibrium with the soil environment $[66,76]$. Therefore, the homogeneity found in the $\delta^{18} \mathrm{O}_{\mathrm{VPDB}}$ values among the pedogenic rocks of the same level $(-6.6 \%$ o to $-7.3 \%$; $n=6)$ indicates that these rocks approached $\delta^{18} \mathrm{O}_{\mathrm{VPDB}}$ values characteristic of the soil water/meteoric water equilibrium. The meteoric/vadose fluids potentially affected the pedogenic oxygen and carbon isotope compositions (see petrography and discussion below). Apparently, the meteoric/vadose fluids influenced the isotopic composition of the HT saddle dolomites "SD1, SD2, and SD3" and blocky calcite cements "CI and CII". In order to calculate the temperature of the fluid that influenced the Bekhme carbonates under near-surface conditions, we used Dowrkin's equation [77], linking the oxygen isotopic composition of the pedogenic carbonates (calcrete) to the temperature of crystallization as follows:

$$
\delta^{18} \mathrm{Occ}(\% \text {, PDB })=0.49\left(\mathrm{~T}\left[{ }^{\circ} \mathrm{C}\right]\right)-12.65,
$$

where $\delta^{18}$ Occ is the mean oxygen isotope value of pure calcrete $(-6.6 \%$ ). Applying this equation to our samples that were completely recrystallized and altered by calcretization processes gave a calculated diagenetic near-surface temperature of around $13^{\circ} \mathrm{C}$.

\subsection{Time and Duration of Calcrete Exposure: A Response to Sea-Level Fluctuation and Tectonics}

Several aspects controlling the calcrete formation are well known: tectonics, sea-level fluctuations, paleochannel formation, paleolakes, alteration by groundwater, and length of subaerial exposure [78-82]. The timing of calcretization is critical in order to estimate the sea-level fluctuations and tectonics, which are generally deduced from regional unconformities [20-22].

During the Campanian-Maastrichtian times, the High Folded Zone in northern Iraq was affected sporadically by transversal "uplifted" block movements [83], enhancing relative eustatic sea-level changes [84]. The calcrete profile in the Spelek-Sulauk area was superimposed on Bekhme Formation, e.g., reefal boundstones and bioclastic packstones, in a cyclical stacking pattern (Figures 5 and 6). The 
profile showed two remarkable cyclic repetitions of no less than two individual pedogenic calcrete levels sandwiched between the unaltered Bekhme carbonates. The Spelek-Sulauk area experienced, therefore, subaerial exposures and an in situ pedogenic alteration, likely during sea-level fluctuations $[72,85,86]$. The development of alveolar septal and root mold structures and the intensity of the microbial diagenetic alteration emphasize that the plants had a role in penetrating the Bekhme carbonates and were active players in the development of pedogenic calcretes during subaerial exposure.

Several studies demonstrated that calcrete profiles can be divided into two main groups: mature and immature [22,87-90]. Well-developed features characterized the mature profile and were distinguished by thick "massive" indurated carbonate and clay accumulation horizons [91-93] with hard laminated crusts $[66,89]$. The immature profile was distinguished by less-developed horizons [66] and the lack of hard laminated crusts [22,94,95].

There is increasing evidence that mature "massive" calcretes, especially the laminar crusts, either record the length of subaerial exposure "duration" [88,96] and/or groundwater movements or evaporation [22,76]. In our study areas, features indicating groundwater movements were not recognized. In contrast to the mature calcretes, the immature ones suggest periods of non-deposition and soil formation features [97]. Reference [98] demonstrated that a long period of exposure (between 1000 and 10,000 years) allows growth of well-developed nodular calcite within the soil.

It was concluded from many ancient calcrete profiles that the duration of the sediment could be deduced from the variation in thickness and maturity of the calcrete and the intertwining of different sediment types $[30,61,96]$. However, the profiles here showed different thicknesses of their internal levels (2-6 m), which, according to previous studies, should suggest a longer exposure period, which was contradicted here. Furthermore, the development of calcrete profiles originated as a result of in situ alteration of Bekhme Formation (Figure 12), not as a response to a new precipitation at the surface, which could either have been from the groundwater movement or from other resources [99-101]. The studied calcrete levels were described as mature and less mature units, with tidal channels locally distributed/interlinked in the calcrete profiles [102]. Tidal-influenced areas were controlled by sea-level fluctuations and rhythms within tidal deposits (Figure 6B-D).

The thin marly laminar crusts $(\sim 4 \mathrm{~cm})$ overlying the irregular erosional surface in the Sulauk profile (Figure 5A) and the lack of such a surface in the Spelek calcrete suggest that the Sulauk profile was significantly influenced by a longer period of non-deposition than the Spelek area (Figure 5A,B). However, nodular calcite and scarce laminar crusts played a role in the Spelek calcrete profile; thus, this area was interpreted as a less mature profile, possibly related to a local regression [103].

As Bekhme Formation was deposited during the Campanian-Maastrichtian times encompassing several million years; accordingly, the length and the cyclical stacking of calcrete levels were developed in relatively contemporaneous events (i.e., during the period of whole deposition of Bekhme Formation). The development of the mature and less-developed mature calcretes in the Sulauk and Spelek areas does not necessarily imply a long period of exposure (see above) (i.e., periods more than the deposition of Bekhme Formation) (see Reference [97]). However, Reference [98] suggested a period between 1000 and 10,000 years as a long exposure for similar deposits. Reference [104] connected the thickness of the calcrete profile to the length of exposure and suggested a $1 \mathrm{~cm}$ (thickness)/2000 years accumulation rate. Nevertheless, the processes implied in the calcrete development were more complex, and the calcrete profile described here displayed mature to less mature levels as a result of multiple short periods of exposures during the Campanian-Maastrichtian times. Well-defined in situ pedogenic calcrete formation (altered Bekhme Formation), and the discontinuous erosional surface in the Sulauk area, based on lateral accretion, the presence of two pedogenic levels interbedded within the Bekhme carbonates, cyclical stacking, and thin laminar layers of rhythmicity of a "tide-influenced area", suggest short-term tidal currents and depositional environments (Figures 4-6).

Reference [105] suggested that tectonics was the dominant factor leading to the polyphased folding and faulting within the Upper Cretaceous series along the Harir and Safin anticlines. The author detailed the geodynamic structure of the Harir anticline with several uplifts and intensive 
paleo-stress affecting the SW limb of Harir anticline during the Late Cretaceous. Reactivation of these faults during the Alpine "Late Cretaceous" affected Bekhme Formation in NE Iraq [106]. Folding of the Harir anticline during Late Cretaceous was related to uplifting movements above sea level [14]. This would have led to relative sea-level fluctuations in Spelek-Sulauk area. Therefore, the primary control of the evolution of pedogenic profiles (2-6 mthick in our case) was tectonic in nature (Figure 7A), and general re-activation of the fault systems, in particular the strike-slip faults, affected the relative sea-level fluctuations. Therefore, the development of the well-formed "massive" calcrete was related to the tectonic evolution. The above points show that the upper part of the Bekhme Formation was exposed to surface conditions during falling of the sea level, and was altered by plant activities that had a role in the "in situ" alteration of Bekhme carbonate. The microcrystalline calcites between the laminar and the fenestral alveolar textures could have been precipitated either by meteoric/vadose waters or by biotic controlled mechanisms during subaerial exposure. The observed fibrous needle calcitic and bladed cements indicate that precipitating fluids potentially had low to intermediate salinities. The meteoric fluids influencing the late diagenetic sequence were confirmed by cathodoluminescence, showing that different fluids were involved during this event (Figure 11E). The chocolate luminescence probably referred to reducing conditions generated by biogenic mechanisms (fibrous cement), while biogenic mechanisms displayed a thick dull luminescence suggesting oxidative conditions in the laminar texture. The subsequent arrangement of thin bright and thick dull luminescence in chalky textures was probably due to variations of the redox conditions or mixing of two sources of fluids with different acidity.

High-energy currents reworked partially semi-rounded pebble- and cobble-sized calcarenites and produced graded bedding (Figure 6B). These reworked calcarenites overlaid the planar laminar structure that was intensively bioturbated (Figure 6C,E), in places where the cross-bedded structures overlaid the calcrete profile (Figure 6B). These laminations were characterized by a repetitive dark peloidal/bioclastic grainstones and white microbial laminar boundstones that overlaid a meter-thick unit of boulders embedded in muddy deposits. Alternate vertical white and dark laminae could represent tidal rhythmites $[11,22]$. The sudden shift from the rhythmites to the calcrete horizon more likely referred to episodes of subaerial exposure due to further submergence related to sea level fluctuation [30]; see Figure 9 with or without tectonics during the Late Cretaceous $[107,108]$. The occurrence of crustacean fossils and abundant bioturbation within the Bekhme Formation, in addition to the interaction between the low-energy microbial bindstones and high-energy-peloidal/bioclastic grainstones, is similar to marine intertidal settings and, therefore, suggests a tidal-influenced system [22,109]. Consequently, sea-level fluctuations and tectonics interplay were the driving processes leading to multiple short episodes of subaerial exposure during falling and rising sea water in tidal flats during the deposition of Bekhme Formation.

The cyclic sedimentary record of the Bekhme Formation, including the calcretes in the studied area, was injected by hydrothermal fluids and controlled by strike-slip movement. This movement was explained in detail by Reference [13] during the Late Cretaceous, especially in the Harir and Safin anticlines.

It is possible to conclude that the saddle dolomites and blocky calcites, in addition to earlier seawater dolomitization, predated the calcrete products in the Spelek-Sulauk area. The tectonic movements enhanced sea-level fluctuation and, directly after deposition of Bekhme Formation, HT fluids channeled their way along fractures and weakness zones throughout Bekhme Formation (Figure 15). Saddle dolomites and blocky calcites were affected and disturbed by calcrete features such as bio-brecciation of saddle dolomites and blocky calcites, corrosion and dissolution of saddle fragments floated in the alveolar texture, and geometrical relationships (Figure 10G,H and Figure 11F). These reported macro features and microfacies offered strong evidence that Bekhme Formation underwent at least two short episodes of cyclic repetitive events of calcrete carbonate during Campanian-Maastrichtian times. These features included (i) a rhythmic sedimentation and expeditiously shifting sediments from calcrete products to planar laminations layers (Figures 5 and $6 \mathrm{~B}, \mathrm{C}$ ); (ii) alveolar textures and 
microbial diagenetic effects on the original substrate (Figure 9G,H, Figure 10G,H, Figure 11A-H, and Figure 12A-E); (iii) planar laminations, with a thinning-upward trend, the local wavy ripple laminations, and an intensive bioturbation related to "Thalassinoides", attesting to tidal-influenced conditions (Figure 6C-F) (e.g., Reference [110]); and (iv) the unidirectional planar laminar "rhythmicity" of silt-sized carbonate sediments/silicates, the vertical and horizontal branched-shaped burrows, the crustacean burrows (Thalassinoides), the peloidal packstones/grainstones, and the microbial laminated mat interbedded with loose friable mudstone and rhombohedral dolomite cements (Figure 10G).

Finally, the complex interplay between sea level and tectonic events produced multiple phases of submergence and emergence during the deposition of Bekhme Fm and led to the formation of two calcrete bodies sandwiched within the formation (Figure 15).
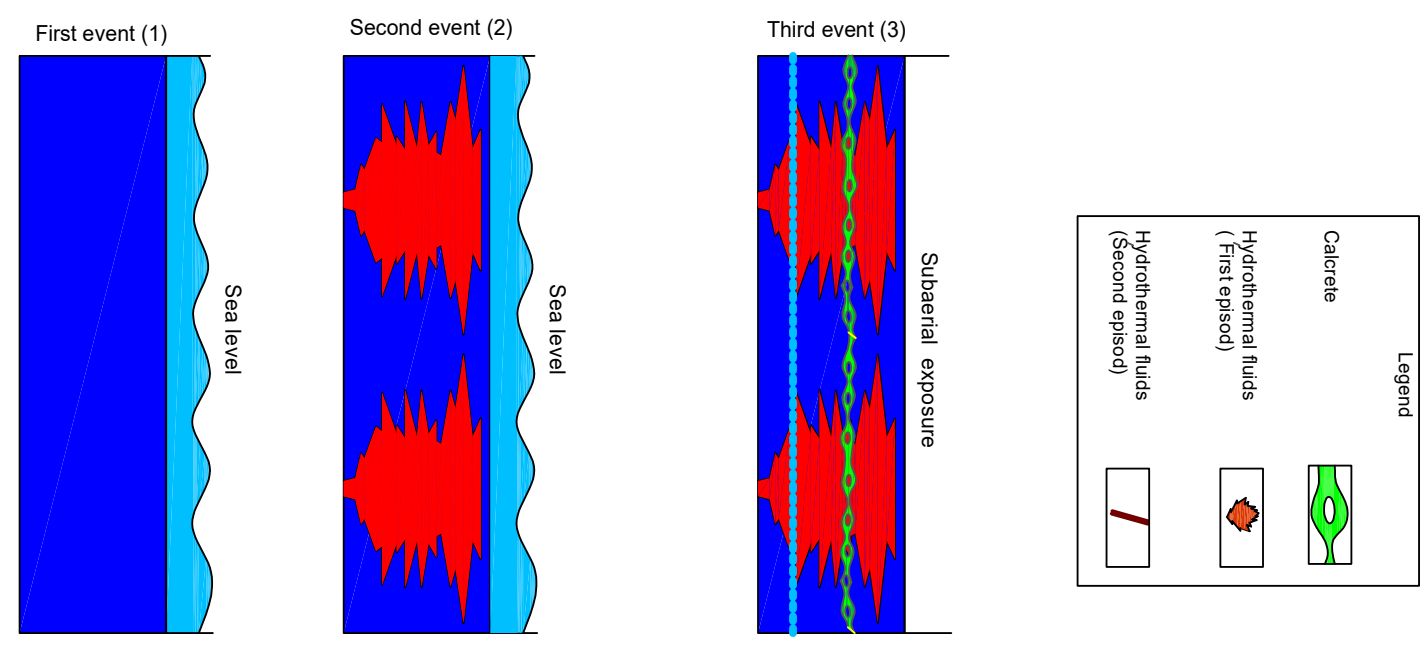

$$
\begin{aligned}
& \infty \\
& \mathbb{D} \\
& \Phi \\
& \stackrel{D}{\Phi} \\
& \stackrel{D}{D}
\end{aligned}
$$

Fifth event (5)
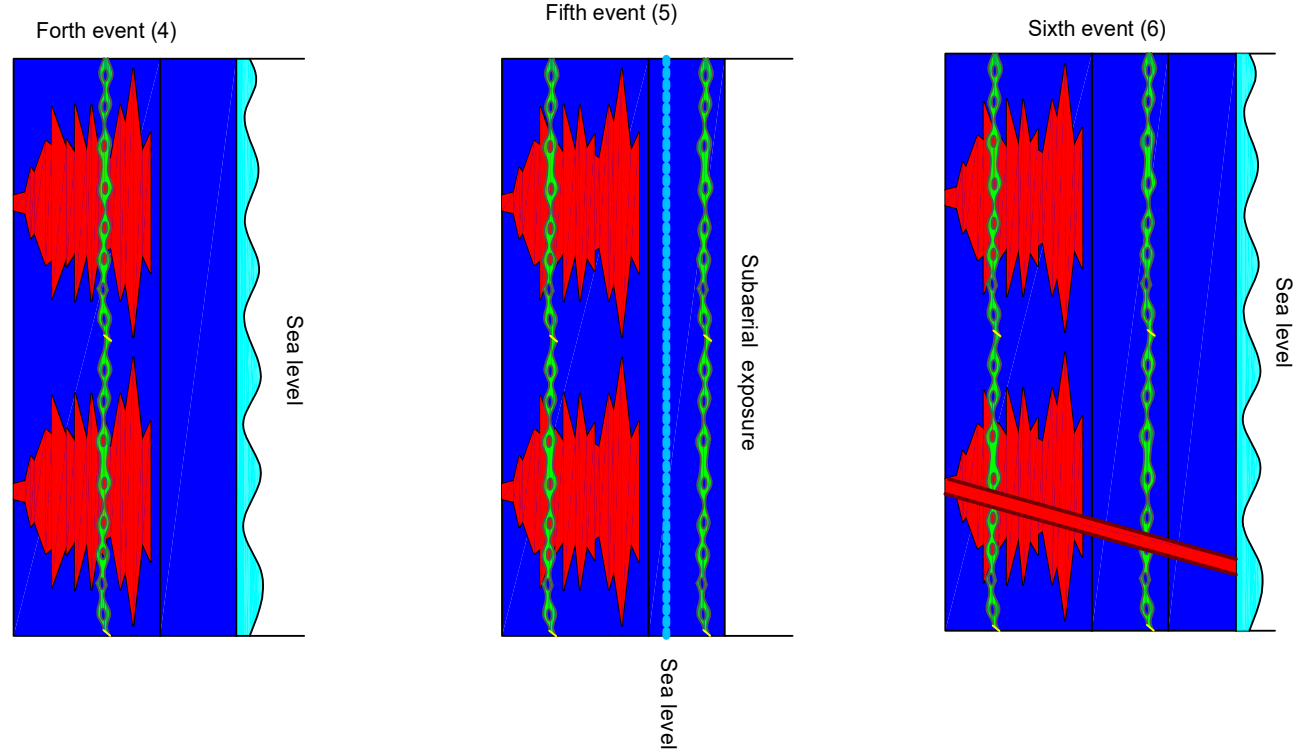

Figure 15. Block diagram illustrating the injection of hydrothermal fluids and calcretization influences in the Spelek-Sulauk area. Hydrothermal fluids followed the strike-slip fault to migrate along the fractures and weakness zones. Biogenic features penetrated hydrothermal products and entrained into Bekhme Formation. This model gives a detailed description of the paragenetic sequence of the area. 


\subsection{Tidal and Channel Signals in the Bekhme Formation}

During the Late Cretaceous, the recurrent transgression and regression of sea level and tectonics [111] had a significant role in the development of the pedogenic calcretes and channel sediments in the studied area, which allowed the development of tidal-dominated conditions. The Sulauk calcrete profile is sharply truncated by an overlying V-shaped channel that displays rhythmic deposition of cross-bedded structures (Figure 6B). In places, planar laminations were underlain by cobble and pebble calcarenites of the Bekhme deposits embedded in muddy deposits (Figure 6C). The resulting thinning-upward succession displays cyclic white and dark layers of peloidal-bioclastic packstones/grainstones and microbial bindstones (Figure 11G). This rhythmicity and the graded bedding in this region have similar features to the tidal channel deposits previously documented along the Mussafah Channel near Abu Dhabi [112]. Moreover, Reference [113] documented extensive microbial mats and bioclastic/oolitic/peloidal facies in intertidal/subtidal zones as a result of along-shore current. The random vertical distribution and deeply penetrating burrows in these layers indicate loosely lithified deposits during high-energy conditions in subtidal/intertidal settings and low-energy conditions in intertidal/subtidal environments. Vertical burrows in the observed microfacies and graded bedding, in addition to muddy intraclasts with minor quartz filling the bioclastic skeleton pores (Figure 11G,H), suggest high-energy environments in the tidal channel, the same as those reported by Reference [114]. Deposition of microbial mats and peloidal bioclastic packstones/grainstones were produced by low- and high-energy turbidity currents, respectively. Oncoidal microfacies, organic material, and floated calcarenites with cobble- and pebble-sized grains in a muddy groundmass suggest scrubbing of Bekhme carbonate with fluid muds embedding the large rounded grains. These were transported through tidal-influenced channel deposits within the depositional basin.

Basal large-sized calcarenite fragments, followed by vertical planar lamination with abundant burrows within the Sulauk Section, were induced by multiple short tidal episodes and not by long episodes of tidal currents. Therefore, Bekhme Formation experienced multiple episodes of subaerial exposure during the Campanian-Maastrichtian period, as indicated by the sandwiched calcrete profile within the carbonate Bekhme Formation under the effect of sea-level fluctuation and local tectonic faults.

\section{Conclusions}

1. In the Harir-Safin area, a large volume of the basal parts of Bekhme Formation outcrops were invaded by hydrothermal fluids that produced brecciated dolomitic matrix, which was eventually cemented by saddle dolomites and blocky calcites. This demonstrated that the time of fracturing was contemporaneous with the potential of hydrothermal fluids.

2. The calcrete profile superimposed on the brecciated zone, followed by the uninterrupted continuous deposition of Bekhme deposits, clearly shows the result of submergence and emergence of Bekhme Formation during Campanian-Maastrichtian times.

3. The vertical lithological variability highlights a cyclic repetition of $2-6-\mathrm{m}$-thick calcrete profiles sandwiched within the Bekhme carbonates. This suggested that the combined effect of hydrothermal fluids and calcretization processes was the result of the Zagros Orogeny and folding tectonics during the Upper Cretaceous, which channeled and facilitated the movement of the hydrothermal fluids.

4. Deep hot fluids that migrated through horizontal/sub-vertical fractures within the Upper Cretaceous carbonates precipitated three types of saddle dolomites (SD1, SD2, and SD3) and two types of blocky calcites (CI and CII). It is also concluded that the pore spaces were probably rejuvenated even after the deposition of Bekhme Formation.

5. Bekhme Formation contained up to two pedogenic calcrete levels within each outcrop, formed by in situ alteration processes of Bekhme host carbonates exposed to sea-level fluctuation and tectonics.

6. Emergence and subaerial exposure was further manifested by the V-shaped paleochannel structures incising into the underlying calcrete profile, with channel sediments and preserved internal cross-bedding truncating the calcrete facies. 
7. Strong microbial activity by mainly fungi and bacteria within the calcretes was shown to have played an important role in producing specific microbial diagenetic features such as microporosity, dissolution, mineralization, micritization, grain-grain bridging, and cementation with neominerals. Using SEM, the abundant mineralized microbial forms, many times imbedded in EPS films, were seen closely bound to those diagenetic features.

8. Petrographic observations and geochemical evidence indicated that the mixing of meteoric/vadose waters corresponded to the calcretization events. This was better confirmed by the inverse-J Lohmann curve (1988) that fit our isotope curve using $\delta^{18} \mathrm{O}_{\mathrm{VPDB}}$ and $\delta^{13} \mathrm{C}_{\mathrm{VPDB}}$ values.

Author Contributions: Conceptualization, N.S., A.P. and K.K. and H.M.; methodology N.S.; software, N.S.; validation, N.S., A.P. and K.K.; formal analysis, N.S. and K.K. and A.P.; investigation, N.S., A.P. and K.K.; resources, N.S.; data curation, N.S.; writing—original draft preparation, N.S. and A.P.; writing-review and editing, N.S., A.P., K.K., and H.M.; visualization, N.S.; supervision, A.P., H.M., and K.K.; project administration, N.S., A.P., H.M.; funding acquisition, A.P.

Funding: This research was funded by Universite Libre de Bruxelles/Geology, Belgium.

Conflicts of Interest: The authors declare no conflicts of interest.

\section{References}

1. Biehl, L.R.B.C.; Kukla, P.A. Impacts of hydrothermal dolomitization and thermochemical sulfate reduction on secondary porosity creation in deeply buried carbonates: A case study from the Lower Saxony Basin, northwest Germany. AAPG Bull. 2016, 100, 597-621. [CrossRef]

2. Nader, F.; López-Horgue, M.; Shah, M.; Dewit, J.; Garcia, D.; Swennen, R.; Iriarte, E.; Muchez, P.; Caline, B. The Ranero Hydrothermal Dolomites (Albian, Karrantza Valley, Northwest Spain): Implications on Conceptual Dolomite Models. Oil Gas Sci. Technol. Rev. d'IFP Energ. Nouv. 2012, 67, 9-29. [CrossRef]

3. Wilson, N.S.F.; Stasiuk, L.D.; Fowler, M.G. Origin of organic matter in the Proterozoic Athabasca Basin of Saskatchewan and Alberta, and significance to unconformity uranium deposits. Bull. Geol. Surv. Can. 2007, 588, 325-339.

4. Davies, G.R.; Smith, L.B. Structurally controlled hydrothermal dolomite reservoir facies: An overview. AAPG Bull. 2006, 90, 1641-1690. [CrossRef]

5. Conliffe, J.; Burden, E.T.; Wilton, D.H.C. The Use of Integrated Fluid Inclusion Studies for Constraining Petroleum Charge History at Parsons Pond, Western Newfoundland, Canada. Minerals 2017, 7, 39. [CrossRef]

6. Wright, V.P. Paleosols in shallow marine carbonate sequences. Earth Sci. Rev. 1994, 35, 367-395. [CrossRef]

7. Blatt, H.; Middlenton, V.; Murry, R. Origin of Sedimentary Rocks, 2nd ed.; Prentice-Hall Inc.: Englewood Cliffs, NJ, USA, 1980; p. 634.

8. Cantarero, I.; Travé, A.; Baqués, V. Polyphasic hydrothermal and meteoric fluid regimes during the growth of a segmented fault involving crystalline and carbonate rocks (Barcelona Plain, NE Spain). Geofluids 2014, 14, 20-44. [CrossRef]

9. English, J.M.; Lunn, G.A.; Ferreira, L.; Yacu, G. Geologic evolution of the Iraqi Zagros, and its influence on the distribution of hydrocarbons in the Kurdistan region. AAPG Bull. 2015, 99, 231-272. [CrossRef]

10. Dunnington, H.V.; Wetzel, R.; Morton, D.M. Lexique stratigraphique international Asie. Fasc. Iraq. Paris 1959, 10, 333.

11. Mansurbeg, H.; Morad, D.; Othmana, R.; Morad, S.; Ceriani, A.; Al-Aasm, I.; Kolo, K.; Spirov, P.; Proust, J.; Préat, P.; et al. Hydrothermal dolomitization of the Bekhme formation (Upper Cretaceous), Zagros Basin, Kurdistan Region of Iraq: Record of oil migration and degradation. Sediment. Geol. 2016, 341, 147-162. [CrossRef]

12. Ballato, P.; Uba, C.; Landgraf, A.; Strecker, M.; Sudo, M.; Stockli, D.; Friedrich, A.; Tabatabaei, S. Arabia-Eurasia continental collision: Insights from late Tertiary foreland basin evolution in the Alborz Mountains, northern Iran. Geol. Soc. Am. Bull. 2011, 123, 106-131. [CrossRef]

13. Ismail, S.; Kettanah, Y.; Chalabi, S.; Ahmed, A.; Arai, S. Petrogenesis and PGE distribution in the Al-and Cr-rich chromites of the Qalander ophiolite, northeastern Iraq: Implications for the tectonic environment of the Iraqi Zagros Suture Zone. Lithos 2014, 202, 21-36. [CrossRef] 
14. Omar, A. An Integrated Structural and Tectonic Study of the Binabawi-Safin-Bradost Region in Iraqi Kurdistan. Ph.D. Thesis, University of Salahaddin, Erbil, Iraq, 2005.

15. Omar, A.A.; Syan, S.H. Construction of a Structural Model for Harir Anticline within Zagros Fold-Thrust belt, Kurdistan of Iraq. Zanco J. Pure Appl. Sci. 2016, 28, 90-105.

16. László, C.; Ágoston, S.; Tamás, P.; László, K.; Salae, A.T.; Athar, A. Structural evolution of the northwestern Zagros, Kurdistan Region, Iraq: Implications on oil migration. GeoArabia 2012, 17, 81-116.

17. Tessier, B. Upper intertidal rhythmites in the Mont-Saint-Michel Bay (NW France): Perspectives for paleoreconstruction. Mar. Geol. 1993, 110, 355-367. [CrossRef]

18. Greb, S.; Archer, A. Rhythmic sedimentation in a mixed tide and wave deposit, Hazel Patch sandstone (Pennsylvanian), eastern Kentucky coal field. J. Sediment. Res. 1995, 65, 96-106.

19. Archer, D.; Martin, P.; Buffett, B.; Brovkin, V.; Rahmstorf, S.; Ganopolski, A. The importance of ocean temperature to global biogeochemistry. Earth Planet. Sci. Lett. 2004, 222, 333-348. [CrossRef]

20. Yocum, D.A.; De Wet, C.B.; Mora, C.I. Carbonate Lakes in Closed Basins: Sensitive Indicators of Climate and Tectonics: An Example From the Gettysburg Basin (Triassic), Pennsylvania, USA. In Relative Role of Eustasy, Climate, and Tectonism in Continental Rocks; SEPM-Society for Sedimentary Geology: Tulsa, OK, USA, 1998; Volume 59, pp. 191-209.

21. Alonso-Zarza, A.M. Initial stages of laminar calcrete formation by roots: Examples from the Neogene of central Spain. Sediment. Geol. 1999, 126, 177-191. [CrossRef]

22. Tanner, L.; Lucas, S.G. Calcareous paleosols of the Upper Triassic Chinle Group, Four Corner region, southwestern United States. In Paleoenvironmental Record and Applications of Calcretes and Palustrine Carbonates; Alonso-Zarza, A.M., Tanner, L.H., Eds.; Special Paper; Geological Society of America: Pod, CO, USA, 2006; Volume 416, pp. 53-74.

23. Salih, N.; Mansurbeg, H.; Kolo1, K.; Gerdes, A.; Préat, A. In situ U-Pb dating of hydrothermal diagenesis in tectonically controlled fracturing in the Upper Cretaceous Bekhme Formation, Kurdistan Region-Iraq. Int. Geol. Rev. 2019, in press.

24. Brusca, C.; Dessau, G. I giacimenti piombo-zinciferi diS.Giovanni (Iglesias) nel quadro della geologia del Cambricosardo. Ind. Min. 1968, 19, 470-494.

25. Watts, N.L. Quaternary pedogenic calcretes from the Kalahari (southern Africa): Mineralogy, genesis and diagenesis. Sedimentology 1980, 27, 661-686. [CrossRef]

26. Goudie, A.S. Calcrete. In Chemical Sediments and Geomorphology; Goudie, A.S., Pye, K., Eds.; Academic Press: London, UK, 1983; pp. 93-131.

27. Wright, V.; Tucker, M. Calcretes: An introduction. In Calcretes. International Association of Sedimentologists; Wright, V.P., Tucker, M.E., Eds.; Reprint Series 2; Blackwell Scientific Publications: Oxford, UK, 1991; p. 352.

28. Milnes, A. Calcrete. Development in Earth Surface Processes. In Weathering, Soils and Paleosol; Martini, I.P., Chesworth, W., Eds.; Elsevier: Amsterdam, The Netherlands, 1992; Volume 2, pp. 309-347.

29. Kahle, C.F. Origin of subaerial Holocene calcareous crusts: Role of algae, fungi and sparmicritisation. Sedimentology 1977, 24, 413-435. [CrossRef]

30. Adams, A. Calcrete profiles in the Eyam Limestone (Carboniferous) of Derbyshire: Petrology and regional significance. Sedimentology 1980, 27, 651-711. [CrossRef]

31. Wright, V.P.; Platt, N.H.; Wimbledon, W.A. Biogenic laminar calcretes: Evidence of calcified root-mat horizons in paleosols. Sedimentology 1988, 35, 603-620. [CrossRef]

32. Fu, Q.; Qing, H.; Bergman, K.M. Dolomitized calcrete in the Middle Devonian Winnipegosis carbonate mounds, subsurface of south-central Saskatchewan, Canada. Sediment. Geol. 2004, 168, 49-69. [CrossRef]

33. Denver, L.E. Paleoenvironmental Significance of Lower Permian, Low-Relief, Cryptalgal Deposits of the Midcontinent. Master's Thesis, University of Kansas, Lawrence, KS, USA, 1985.

34. Kolo, K.; Mamet, B.; Préat, A. Dichotomous filamentous dolomite crystal growth in the Lower Carboniferous from Northern France: A possible direct production of fungal activity? In Proceedings of the First Geologica Belgica International Meeting, Leuven, Belgium, 11-15 September 2002; pp. 121-123.

35. Gadd, G.M. Geomycology: Biogeochemical transformations of rocks, minerals, metals and radionuclides by fungi, bioweathering and bioremediation. Mycol. Res. 2007, 111, 3-49. [CrossRef] 
36. Gadd, M.G.; Layton-Matthews, D.; Peter, J.M.; Paradis, S. In situ trace element and sulphur isotope analyses of pyrite constrain timing of mineralization and sources of sulphur in the Howard's Pass SEDEX Zn-Pb District, Yukon. In Targeted Geoscience Initiative 4: Sediment-Hosted Zn-Pb Deposits: Processes and Implications for Exploration; Paradis, S., Ed.; Geological Survey of Canada: Ottawa, ON, Canada, 2015; pp. 58-74.

37. Peter, J.M.; Gadd, M.G.; Layton-Matthews, D. Non-hydrothermal origin of apatite in SEDEX mineralization and host rocks of the Howard's Pass district, Yukon, Canada. Am. Miner. 2016, 101, 1061-1071.

38. Kolo, K.; Konhauser, K.; Prian, J.P.; Préat, A. Probable fungal colonization andcarbonate diagenesis of Neoproterozoic stromatolites from South Gabon, Western Congo Basin. Basin. In The Geology and Resource Potential of the Congo Basin; de Wit, M.J., Guillocheau, F., de Wit, M.C.J., Eds.; Springer: Berlin/Heidelberg, Germany, 2015.

39. Bindschedler, S.; Cailleau, G.; Verrecchia, E. Role of Fungi in the Biomineralization of Calcite. Minerals 2016, 6, 41. [CrossRef]

40. Sánchez-Román, M.; Vasconcelos, C.; Schmid, T.; Dittrich, M.; McKenzie, J.A.; Zenobi, R.; Rivadeneyra, M.A. Aerobic microbial dolomite at the nanometer scale: Implications for the geologic record. Geology 2008, 36, 879-882. [CrossRef]

41. Armenteros, M.; Aristoy, M.C.; Barat, J.M.; Toldrá, F. Biochemical and sensory changes in dry cured ham salted with partial replacement of sodium by a mixture of potassium, calcium and magnesium. Meat Sci. 2012, 90, 361-367. [CrossRef]

42. Kolo, K.; Keppens, E.; Préat, A.; Claeys, P. Experimental observations on fungal diagenesis of carbonate substrates. J. Geophys. Res. Space Phys. 2007, 112. [CrossRef]

43. Verrecchia, P. Fungi and sediments. In Microbial Sediments; Riding, R.E., Awramik, S.M., Eds.; Springer: Berlin/Heidelberg, Germany, 2000; pp. 69-75.

44. Anbu, P.; Kang, C.H.; Shin, Y.J.; So, J.S. Formations of calcium carbonate minerals by bacteria and its multiple applications. SpringerPlus 2016, 5, 250. [CrossRef]

45. Riding, R. Bacterial Biomineralization. In Fundamentals of Geobiology; Knoll, A.H., Canfield, D.E., Konhauser, K.O., Eds.; Wiley: Hoboken, NJ, USA, 2012; pp. 105-130.

46. Gradstein, M.; Ogg, J.G.; Schmitz, M.; Ogg, G. (Eds.) The Geologic Time Scale; Elsevier: Amsterdam, The Netherlands, 2012; p. 1176.

47. Veizer, J.; Hoefs, J. The nature of $\mathrm{O}^{18} / \mathrm{O}^{16}$ and $\mathrm{C}^{13} / \mathrm{C}^{12}$ secular trends in sedimentary carbonate rocks. Geochim. Cosmochim. Acta 1976, 40, 1387-1395. [CrossRef]

48. Pearson, P.N.; Ditchfield, P.W.; Singano, J.; Harcourt-Brown, K.G.; Nicholas, C.J.; Olsson, R.K.; Shackleton, N.J.; Hall, M.A. Warm tropical sea surface temperatures in the Late Cretaceous and Eocene epochs. Nature 2001, 413, 481-487. [CrossRef]

49. Radke, B.; Mathis, R. On the formation and occurrence of saddle dolomite. J. Sediment. Res. 1980, 50, 1149-1168.

50. Searl, A. Saddle dolomite: A new view of its nature and origin. Miner. Mag. 1989, 53, 547-555. [CrossRef]

51. Lohmann, C. Geochemical patterns of meteoric diagenetic systems and their application to studies of paleokarst. In Paleokarst; James, N.P., Choquette, P.W., Eds.; Springer: New York, NY, USA, 1988; pp. 58-80.

52. Longhitano, S.G.; Mellere, D.; Steel, R.J.; Ainsworth, R.B. Tidal depositional systems in the rock record: A review and new insights. Sediment. Geol. 2012, 279, 2-22. [CrossRef]

53. Salih, N.; Kamal, I.; Préat, A. Classical observations and stable isotopes for identification the diagenesis of Jeribe formation at Jambour oil Fields-Kurdistan Region-Iraq. Pet. Sci. Technol. 2019, 37, 1548-1556. [CrossRef]

54. Osborne, M.J.; Swarbrick, R.E. Mechanisms for Generating Overpressure in Sedimentary Basins: A Reevaluation. AAPG Bull. 1997, 81, 1023-1041.

55. Boni, M.; Parente, G.; Bechstädt, T.; De Vivo, B.; Iannace, A. Hydrothermal dolomites in SW Sardinia (Italy): Evidence for a widespread late-Variscan fluid flow event. Sediment. Geol. 2000, 131, 181-200. [CrossRef]

56. Wendte, J.; Chi, G.; Al-Aasm, I.; Sargent, D. Fault/fracture controlled hydrothermal dolomitization and associated diagenesis of the Upper Devonian Jean Marie Member (Redknife Formation) in the July Lake area of northeastern British Columbia. Bull. Can. Pet. Geol. 2009, 57, 275-322. [CrossRef]

57. Shah, M.; Nader, F.; Dewit, J.; Swennen, R.; Garcia, D. Fault-related hydrothermal dolomites in Cretaceous carbonates (Cantabria, northern Spain): Results of petrographic, geochemical and petrophysical studies. Bull. Soc. Geol. Fr. 2010, 181, 391-407. [CrossRef] 
58. Diehl, S.; Hofstra, A.; Koenig, A.; Emsbo, P.; Christiansen, W.; Johnson, C. Hydrothermal Zebra Dolomite in the Great Basin, Nevada-Attributes and Relation to Paleozoic Stratigraphy, Tectonics, and Ore Deposits. Geosphere 2010, 6, 663-690. [CrossRef]

59. Luczaj, J.; Harrison, W., III; Williams, N. Fractured hydrothermal dolomite reservoirs in the Devonian Dundee Formation of the central Michigan Basin. Am. Assoc. Pet. Geol. Bull. 2006, 90, 1787-1801. [CrossRef]

60. Dana, E. A Textbook of Mineralogy; John Wiley and Sons: Hoboken, NJ, USA, 1955; p. 851.

61. Klappa, C. Lichen stromatolites: Criterion for subaerial exposure and a mechanism for the formation of laminar calcrete (caliche). J. Sediment. Petrol. 1979, 49, 387-400.

62. Wright, V. Terrestrial stromatolites and laminar calcretes: A review. Sediment. Geol. 1989, 65, 1-13. [CrossRef]

63. Driese, S.G.; Srinivasan, K.; Mora, C.I.; Stapor, F.W. Paleoweathering of Mississippian Monteagle Limestone preceding development of a lower Chesterian transgressive systems tract and sequence boundary, middle Tennessee and northern Alabama. GSA Bull. 1994, 106, 866-878. [CrossRef]

64. Webb, G.E. Paleokarst, paleosol, and rocky-shore deposits at the Mississippian-Pennsylvanian unconformity, northwestern Arkansas. GSA Bull. 1994, 106, 634-648. [CrossRef]

65. Wright, V. A micromorphological classification of fossil and recent calcic and petrocalcic structures. In Soil Micromorphology: A Basic and Applied Science; Douglas, L.A., Ed.; Development in Soil Science; Elsevier: Amsterdam, The Netherlands, 1990; Volume 19, pp. 401-407.

66. Alonso-Zarza, A.M. Palaeoenvironmental significance of palustrine carbonates and calcretes in the geological record. Earth Sci. Rev. 2003, 60, 261-298. [CrossRef]

67. Alonso-Zarza, M.; Tanner, H. Carbonates in Continental Setting: Facies, Environments and Processes; Developments in Sedimentology; Elsevier: Amsterdam, The Netherlands, 2010; pp. 225-267.

68. Esteban, M.; Klappa, C.F. Subaerial exposure environments. In Carbonate Depositional Environments; Scholle, P.A., Bebout, D.G., Moore, C.H., Eds.; American Association Petroleum Geologists Memoir; American Association Petroleum Geologists: Tulsa, OK, USA, 1983.

69. Verrecchia, E.; Verrecchia, K. Needle-fiber calcite: A critical review and a proposed classification. J. Sediment. Res. 1994, 64, 650-664.

70. Harrison, R.S.; Steinen, R.P. Subaerial crusts, caliche profiles, and breccia horizons: Comparison of some Holocene and Mississippian exposure surfaces, Barbados and Kentucky. GSA Bull. 1978, 89, 385-396. [CrossRef]

71. Klappa, C.F. Biolithogenesis of Microcodium: Elucidation. Sedimentology 1978, 25, 489-522. [CrossRef]

72. Armenteros, I.; Huerta, P. The role of clastic sediment influx in the formation of calcrete and palustrine facies: A response to paleogeographic and climatic conditions in the southeastern Tertiary Duero basin (northern Spain). In Paleoenvironmental Record and Applications of Calcretes and Palustrine Carbonates; Alonso-Zarza, A.M., Tanner, L.H., Eds.; Geological Society of America: Boulder, CO, USA, 2006; Volume 416, pp. 119-132.

73. Alonso-Zarza, A.; Wright, V. Calcretes. In Carbonates in Continental Environments: Processes, Facies and Applications; Alonso-Zarza, A.M., Tanner, L.H., Eds.; Developments in Sedimentology; Elsevier: Amsterdam, The Netherlands, 2010.

74. Wright, V.P. The role of fungal biomineralization in the formation of Early Carboniferous soil fabrics. Sedimentology 1986, 33, 831-838. [CrossRef]

75. Gąsiewicz, A.; Słowakiewicz, M. Palaeozoic climate cycles: Their evolutionary and sedimentological impact. Geol. Soc. 2014, 376, 586.

76. Deocampo, M. The Geochemistry of Continental Carbonates. In Carbonates in Continental Settings, Geochemistry, Diagenesis, and Applications; Alonso-Zarza, A.M., Tanner, L.H., Eds.; Developments in Sedimentology; Elsevier: Amsterdam, The Netherlands, 2010; Volume 62, pp. 1-59.

77. Dworkin, S.; Nordt, L.; Atchley, S. Determining terrestrial paleotemperatures using the oxygen isotopic composition of pedogenic carbonate. Earth Planet. Sci. Lett. 2005, 237, 56-68. [CrossRef]

78. Cecil, C.B. Paleoclimate controls on stratigraphic repetition of chemical and siliciclastic rocks. Geology 1990, 18, 533-536. [CrossRef]

79. Drummond, C.N.; Wilkinson, B.H.; Lohmann, K.C. Climatic control of fluvial-lacustrine cyclicity in the Cretaceous Cordilleran Foreland Basin, western United States. Sedimentology 1996, 43, 677-689. [CrossRef]

80. Hanneman, D.L.; Wideman, C.J. Sequence stratigraphy of Cenozoic continental rocks, southwestern Montana. Geol. Soc. Am. Bull. 1991, 103, 1335-1345. [CrossRef] 
81. Hanneman, D.; Cheney, E.; Wideman, C. Cenozoic sequence stratigraphy of northwestern USA. In Cenozoic Systems of the Rocky Mountain Region; Raynolds, R.G., Flores, R.M., Eds.; SEPM-Society for Sedimentary Geology, Rocky Mountain Section: Tulsa, OK, USA, 2003; pp. 135-156.

82. Hanneman, D.L.; Wideman, C.J. Calcic pedocomplexes-Regional sequence boundary indicators in Tertiary deposits of the Great Plains and western United States. In Paleoenvironmental Record and Applications of Calcretes and Palustrine Carbonates; Alonso-Zarza, A.M., Tanner, L.H., Eds.; Geological Society of America: Pod, CO, USA, 2006; Volume 416, pp. 1-15.

83. Jassim, S.Z.; Goff, J.C. Geology of Iraq; Dolin, Prague and Moravian Museum: Brno, Czech, 2006; p. 341.

84. Karim, K.; Surdashy, A. Sequence stratigraphy of Tanjero Formation, Sulaimanyia area, NE-Iraq. Kurd. Acad. J. 2006, 4, 19-43.

85. Tucker, M.E. Carbonate diagenesis and sequence stratigraphy. In Sedimentology Review; Wright, P.V., Ed.; Blackwell: Oxford, UK, 1993; Volume 1, pp. 51-72.

86. Szulc, J.; Gradziński, M.; Lewandowska, A.; Heunisch, C. The Upper Triassic crenogenic limestones in Upper Silesia (southern Poland) and their paleoenvironmental context. Paleoenviron. Rec. Appl. Calcretes Palustrine Carbonates 2006, 416, 133-151.

87. Lucas, S.G.; Anderson, O.J. Calcretes of the Upper Triassic Owl Rock Formation, Colorado Plateau; Bulletin; New Mexico Museum of Natural History and Science: Albuquerque, New Mexico, 1993; Volume 3, pp. $32-41$.

88. Lucas, S.; Heckert, A.; Estep, J.; Anderson, O. Stratigraphy of the Upper Triassic Chinle Group, Four Corners Region; Guidebook; New Mexico Geological Society: Socorro, TX, USA, 1997; Volume 48, pp. 81-108.

89. Eren, M.; Kadir, S.; Hatipoğlu, Z.; Gül, M. Caliche Development in Mersin Area; TÜBİTAK Project No. 102Y036; TUBITAK: Ankara, Turkey, 2004.

90. Eren, M.; Kadir, S.; Hatipoğlu, Z.; Gül, M. Quaternary calcrete development in the Mersin area, southern Turkey. Turk. J. Earth Sci. 2008, 17, 763-784.

91. Wright, V.P.; Marriott, S.B. A quantitative approach to soil occurrence in alluvial deposits and its application to the Old Red Sandstone of Britain. J. Geol. Soc. 1996, 153, 907-913. [CrossRef]

92. McCarthy, P.; Plint, A. Floodplain paleosols of the Cenomanian Dunvegan Formation. Alberta and British Columbia, Canada: Micromorphology, pedogenic processes and paleontological implication. In Floodplain: Interdisciplinary Approaches; Marriott, S.B., Alexander, J., Hey, R., Eds.; Special Publication; Geological Society: London, UK, 1999; Volume 163, pp. 289-310.

93. Demko, T.M.; Currie, B.S.; Nicoll, K.A. Regional paleoclimatic and stratigraphic implications of paleosols and fluvial/overbank architecture in the Morrison Formation (Upper Jurassic), Western Interior, USA. Sediment. Geol. 2004, 167, 115-135. [CrossRef]

94. Genise, J.; Melchor, R.; Bellosi, E.; Verde, M. Chapter 7: Invertebrate and Vertebrate Trace Fossils from Continental Carbonates. In Carbonates in Continental Settings: Facies, Environments, and Processes; Developments in Sedimentology; Elsevier: Amsterdam, The Netherlands, 2010; Volume 61, pp. 319-369.

95. Kadir, S.; Eren, M.; Külah, T.; Önalgil, N.; Cesur, M.; Gürel, A. Genesis of Late Miocene-Pliocene lacustrine palygorskite andcalcretes from Kırşehir, central Anatolia, Turkey. Clay Miner. 2014, 49, 473-494. [CrossRef]

96. Goldhammer, R.; Dunn, P.; Hardie, L. High frequency glacio-eustatic sea level oscillations with Milankovitch characteristics recorded in Middle Triassic platform carbonates in northern Italy. Am. J. Sci. 1987, 287, 853-892. [CrossRef]

97. Tabor, N.; Montanéz, I.; Kelso, K.; Currie, B.; Shippman, T. A late Triassic soil catena: Landscape controls on paleosol morphology across the Carnian-Age Ischigualasto-Villa Union Basin, Northwestern Argentina. In Paleoenvironmental Record and Applications of Calcretes and Palustrine Carbonates; Alonso-Zarza, A.M., Tanner, L.H., Eds.; Special Paper; Geological Society of America: Pod, CO, USA, 2006; Volume 416, pp. $17-41$.

98. Gile, L.; Hawley, J.; Grossman, R. Soils and Geomorphology in the Basin and Range Area of Southern New Mexico: Guidebook to the Desert Project; Memoir; New Mexico Bureau of Mines and Mineral Resources: Socorro, New Mexico, 1981; Volume 39, p. 222.

99. Brewer, R. Fabric and Mineral Analysis of Soils; Wiley and Sons: New York, NY, USA, 1964.

100. Gile, L.; Peterson, F.; Grossman, B. The K horizon: A master soil horizon of carbonate accumulation. Soil Sci. 1965, 99, 74-82. [CrossRef]

101. Bal, L. Carbonate in soils: A theoretical consideration on, and proposal for its fabric analysis, II and I. Neth. J. Agric. Sci. 1975, 23, 163-176. 
102. Reinhardt, E.; Sigleo, W. Paleosols and Weathering Through Geological Time: Principles and Applications; The Geological Society of America: Boulder, CO, USA, 1988; p. 211.

103. Etthenson, F.; Dever, G., Jr.; Grow, J. A paleosol interpretation for profiles exhibiting subaerial exposure "crusts" from the Mississippian of the Appalachian Basin. In Paleosols and Weathering Through Geologic Time: Principles and Applications; Reinhartdt, W.R., Sigleo, J., Eds.; Special Paper; Geological Society of America: Pod, CO, USA, 1988; Volume 216, pp. 49-79.

104. Robbin, D.; Stipp, J. Depositional rate of laminated soilstone crusts, Florida Keys. J. Sediment. Petrol. 1979, 49, 175-178.

105. Bolton, C. The Geology of Chwarta (K5) and Halabja (K6); Report No.271; Geological Survey, Mineralogy: Baghdad, Iraq, 1958; p. 117.

106. Numan, N. Discussion on dextral transportation in Late Cretaceous continental collision, Sanandaj-Sirjan Zone, western Iran. J. Struct. Geol. 2001, 23, 2033-2034. [CrossRef]

107. Campbell, A. Unconformities in Seismic Records and Outcrops. Ph.D. Thesis, Amsterdam, Free University, Amsterdam, The Netherlands, 1992.

108. Jin, J.; Bergman, K. Sequence stratigraphy of the Middle Devonian Winnipegosis carbonate-prairie evaporate transition, southern Elk Point Basin. Carbonates Evaporites 1999, 14, 64-83. [CrossRef]

109. Pomoni-Papaioannou, F. Facies analysis of Lofer cycles (Upper Triassic), in the Argolis Peninsula (Greece). Sediment. Geol. 2008, 208, 79-87. [CrossRef]

110. Greg, M.B.; Murray, K.G.; Beverly, A.B.; George, P. An example of a highly bioturbated, storm-influenced shoreface deposit: Upper Jurassic Ula Formation, Norwegian North Sea. J. Sedimentol. 2013, 61, 1261-1285.

111. Zebari, M.; Burberry, C. $4 \mathrm{D}$ evolution of anticlines and implications for hydrocarbon exploration within the Zagros Fold Thrust Belt, Kurdistan Region, Iraq. GeoArabia 2015, 20, 161-188.

112. Knaust, D.; Curran, H.; Dronov, A. Shallow-marine carbonates. In Trace Fossils as Indicators of Sedimentary Environments; Knaust, D., Bromley, R.G., Eds.; Developments in Sedimentology; Elsevier: Amsterdam, The Netherlands, 2012; pp. 705-750.

113. Jahnert, R.J.; Collins, L.B. Controls on microbial activity and tidal flat evolution in Shark Bay, Western Australia. Sedimentology 2013, 60, 1071-1099. [CrossRef]

114. Lucas, S.G.; Spielmann, J.A. Triassic of the American West: Bulletin 40; New Mexico Museum of Natural History and Science: Albuquerque, NM, USA, 2007; p. 247.

(C) 2019 by the authors. Licensee MDPI, Basel, Switzerland. This article is an open access article distributed under the terms and conditions of the Creative Commons Attribution (CC BY) license (http://creativecommons.org/licenses/by/4.0/). 